\title{
Potential influence of offshore oil and gas platforms on the feeding ecology of fish assemblages in the North Sea
}

\author{
Toyonobu Fujii* \\ Oceanlab, School of Biological Sciences, University of Aberdeen, Main Street, Newburgh, Aberdeenshire AB41 6AA, UK
}

\begin{abstract}
This article presents results from the first detailed study on the feeding habits of fish assemblages associated with offshore oil and gas platforms in the North Sea. Multi-seasonal sampling was conducted at one of the oil platforms located in the central North Sea between September 2010 and January 2014 to characterise temporal variation in the stomach contents of different fish species. A total of 6 fish species were recorded, including commercially important gadoids such as saithe Pollachius virens, haddock Melanogrammus aeglefinus and cod Gadus morhua. Saithe fed predominantly on euphausiids and haddock consumed a large proportion of ophiuroids, whereas cod were mainly piscivorous. The prey compositions were significantly different between species, indicating the presence of interspecific prey resource partitioning among those species. To further investigate possible links between the feeding habits of the most dominant fish species, saithe, and the physical presence of offshore platforms across the North Sea, a separate set of stomach data was collected during the 2012 Quarter 3 International Bottom Trawl Survey aboard the FRV 'Scotia'. The multivariate analysis of both data sets showed that the observed spatio-temporal variability in the saithe diet was significantly explained by proximity to the nearest offshore platforms and changes in water temperatures, which appear to reflect patterns of euphausiid availability over space and time. The physical presence of the offshore structures may potentially affect the distribution/availability of zooplankton (i.e. euphausiids) and thereby influence the feeding behaviour of saithe and any other marine populations that are interconnected to the dynamics of such trophic interactions.
\end{abstract}

KEY WORDS: Artificial reefs - Offshore oil and gas platforms - Marine feeding ecology · Euphausiids $\cdot$ Fish assemblages $\cdot$ North Sea

\section{INTRODUCTION}

During the last several decades, marine ecosystems have been changing in the context of increasing anthropogenic influences (Halpern et al. 2008, Hoegh-Guldberg \& Bruno 2010). Understanding the dynamic interactions between human activities and the ecology of fish populations is one of the essential prerequisites for the implementation of effective management of marine ecosystems (Stelzenmüller et al. 2010). The North Sea is a large semi-enclosed marine ecosystem of the northeastern Atlantic Ocean, and it has long been a vital ground for the

${ }^{*}$ Corresponding author: t.fujii@abdn.ac.uk exploitation of natural resources. The North Sea supports one of the world's most active fisheries (Ducrotoy et al. 2000), while the history of hydrocarbon exploration has led to the installation of many (>500) offshore oil and gas platforms across the region (OSPAR 2012). Increasing numbers of existing offshore platforms, however, are approaching the end of their commercial lives; to date, $7 \%$ of existing North Sea installations have already been decommissioned, and virtually all of the infrastructure is expected to require decommissioning over the next $30 \mathrm{yr}$ (Royal Academy of Engineering 2013). In this sense, the North Sea provides an ideal study site for

() The author 2016. Open Access under Creative Commons by Attribution Licence. Use, distribution and reproduction are unrestricted. Authors and original publication must be credited. 
investigating the dynamic patterns of interactions between fish populations and anthropogenic as well as natural influences. The long-term objective of this research is to investigate the effect of the physical presence of offshore oil and gas installations on the behaviour and movement of associated fish species to identify the role of large fixed subsea structures in the ecology of fish populations in the North Sea as well as other offshore areas across the world.

In recent years, studies have shown that the physical presence of offshore platforms may have beneficial effects for fisheries because they function as artificial reefs that attract marine life and thereby lead to increased numbers of economically important fishes in their proximity (e.g. Claisse et al. 2014, Friedlander et al. 2014, Pradella et al. 2014). While there is growing evidence to confirm that a variety of fish species aggregate around artificially installed hard structures in marine environments worldwide (e.g. Stanley \& Wilson 1997, Fabi et al. 2004, Love \& York 2005), the mechanism that underpins this hypothesis is not fully understood. Enhanced food availability is one of several proposed mechanisms which may be responsible for the attraction of fish (e.g. Page et al. 2007). For example, an elevated abundance of pouting Trisopterus luscus has been reported around offshore wind turbines located in the southern part of the North Sea, probably due to the enhanced provision of prey species that live on the structures (Reubens et al. 2011). Similarly, both saithe Pollachius virens and cod Gadus morhua are the 2 most frequently observed fish species aggregating around sea cage structures for salmon farming in coastal waters in Norway, and diet and condition data indicated that wild saithe and cod benefited from their associations with salmon farms due to access to greater amounts of food (Dempster et al. 2011). However, there is little published information on the feeding habits of fish assemblages in association with the physical presence of offshore oil and gas installations in the North Sea. Fish can change behaviour and migration pattern according to food availability (Nedreaas 1987), and feeding conditions surrounding offshore installations could therefore be one of the driving forces, among other major factors such as climate change and fishing pressure, which may regulate the distribution, abundance and movement of associated fish populations in the North Sea.

The aim of this study is to characterise spatiotemporal dynamics in the feeding habits of fish assemblages in association with offshore oil and gas platforms in the North Sea. This will be accomplished by investigating (1) temporal variation in the stomach contents of different fish species sampled at one of the offshore oil platforms in the North Sea to examine the degree of interspecific overlap/partitioning in their utilisation of prey resources available at the platform; and (2) stomach contents data of saithe $P$. virens, the most dominant fish species closely associated with offshore structures, by using both spatial samples (obtained from a large-scale bottom trawl survey) and temporal samples (obtained at the platform) and thereby analysing the spatio-temporal variation in saithe stomach contents in relation to several biotic and abiotic explanatory variables to identify those factors which determine the observed dietary trends across the North Sea.

\section{MATERIALS AND METHODS}

The fish used for this study were collected using 2 separate sampling methods: (1) baited fish traps at BP's Miller platform located in the northern central North Sea and (2) on board the FRV 'Scotia' during the 2012 Quarter (Q) 3 International Bottom Trawl Survey (IBTS) across the North Sea (Fig. 1).

\section{Sampling at the Miller platform}

The Miller platform is situated in the northern central part of the North Sea (Fig. 1). The platform was installed in 1991 on a dense sandy seafloor in water depths of approximately $103 \mathrm{~m}$. The submerged section of the platform is a large steel jacket construction with numerous cylindrical cross members, providing a complex lattice structure and a large surface area throughout the entire water column, which represents one of the typical platform structures found in this region.

From September 2010 to January 2014, fish sampling was conducted 4 times a year covering all 4 seasons (i.e. Q1: January to March [winter]; Q2: April to June [spring]; Q3: July to September [summer]; Q4: October to December [autumn]) in the immediate vicinity of the Miller platform. The sampling was carried out using 3 baited fish traps attached to a single mooring rope which was anchored to the sea bottom at one end and secured to the lower deck of the platform at the other. Each fish trap unit comprised a main aluminium supporting framework (2.7 m width $\times 2.7 \mathrm{~m}$ length $\times 1.2 \mathrm{~m}$ height) covered with 2 sheets of trammel nettings (inner mesh size: $51 \mathrm{~mm}$; outer mesh size: $305 \mathrm{~mm}$ ) with a bait container attached to the central part of the unit. Fresh mackerel Scomber 


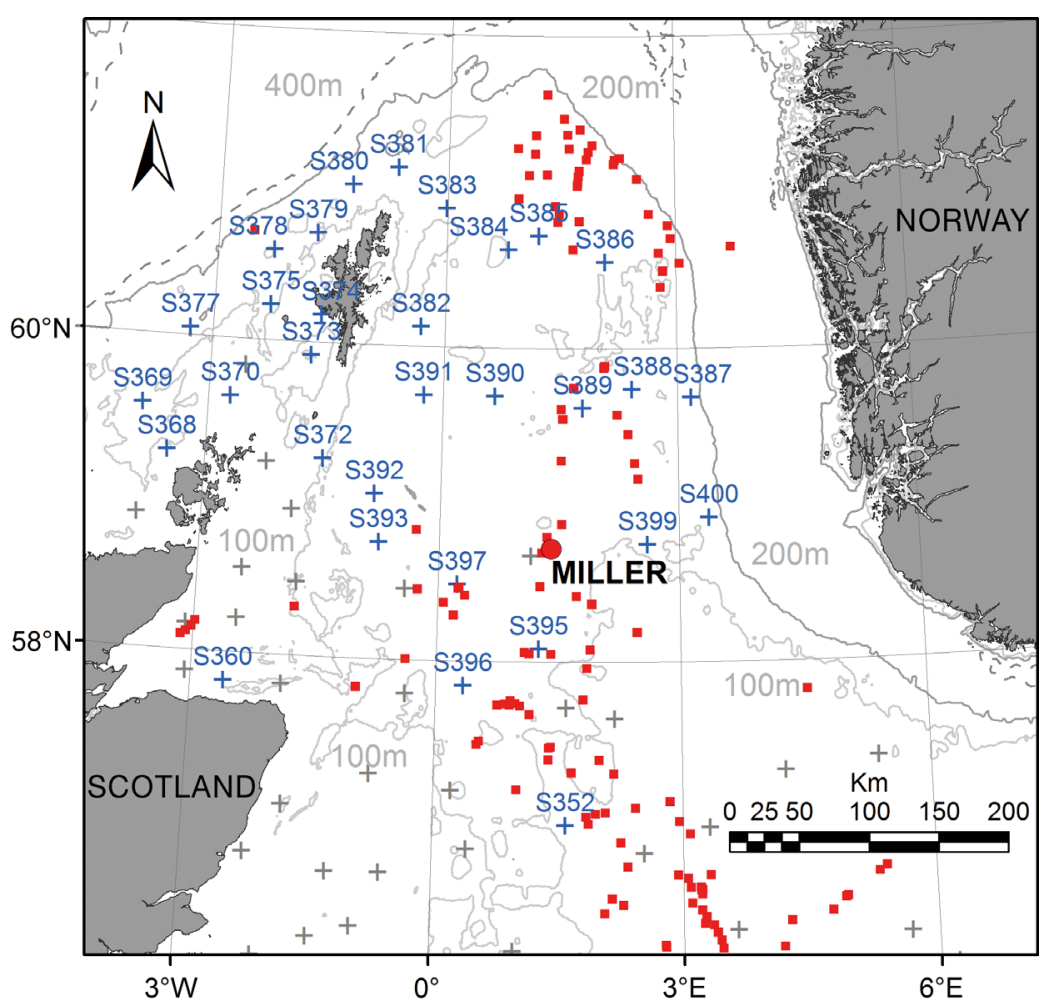

Fig. 1. Northern and central part of the North Sea showing the locations of offshore platforms (red squares), the Miller platform (red circle) and bottom trawl survey stations where saithe was present (blue cross) and absent (grey cross)

scombrus was used as bait (approximately $700 \mathrm{~g}$ per fish trap), and when the mooring system was deployed, the 3 fish traps were maintained at approximately $10 \mathrm{~m}$ (surface), $50 \mathrm{~m}$ (intermediate) and $100 \mathrm{~m}$ (bottom) depths and remained in the water for $>12.5 \mathrm{~h}$ so that each soak time could cover at least 1 tidal cycle per deployment.

Each fish trap was equipped with a temperature sensor, recording the water temperature $\left({ }^{\circ} \mathrm{C}\right)$ at 10 min intervals. The sampling procedure was replicated 3 times on consecutive days per season. Upon retrieval of the fish traps, all the fish samples were sorted, identified and enumerated, and body size (total length, $L_{\mathrm{T}}$ ) of each individual was measured to the nearest $\mathrm{cm}$. The stomachs were extracted immediately on board the platform and frozen at $-20^{\circ} \mathrm{C}$ for subsequent analysis.

\section{Sampling in the IBTS survey on the FRV 'Scotia'}

Saithe Pollachius virens is known to be strongly associated with offshore oil and gas installations, particularly in the northern part of the North Sea (e.g.
Aabel et al. 1997, Soldal et al. 2002, Guerin 2009), and therefore stomach contents data specifically for saithe in the wider North Sea were collected during the 2012 Q3 IBTS aboard the FRV 'Scotia' between 22 July and 11 August. A bottom trawl net (Grande Ouverture Verticale [GOV]) was used to sample demersal fishes at 85 stations across the North Sea. The survey grid was based on an ICES statistical rectangle of approximately $30 \times 30$ nautical miles $\left(0.5^{\circ}\right.$ latitude $\times 1^{\circ}$ longitude). Details on the sampling protocols are available in the IBTS survey manual (ICES 2010). Temperature profile was first recorded near the position of each sampling station. The trawl net was then towed for approximately $30 \mathrm{~min}$. The cod end of the GOV trawl net had a smaller mesh size $(200 \mathrm{~mm}$ at the opening and $20 \mathrm{~mm}$ at the codend) than the inner net of the baited fish trap at the Miller platform (305 $\mathrm{mm}$ at the outer and $51 \mathrm{~mm}$ at the inner mesh). Further, there may be a potential size bias in fish individuals caught by the baited fish trap at the Miller platform when compared with the trawling methods because smaller size classes tend to have different dietary requirements, and they may not therefore be susceptible to baiting. Thus, the minimum size of fish caught by the Miller fish trap was $17 \mathrm{~cm}$ (long rough dab Hippoglossoides platessoides), and the 0-group of any fish species would not be expected to be caught by this fish trap. For this reason, from each trawl catch where saithe were present, a maximum of 10 individuals were randomly extracted over the whole range of sizes except for the 0 -group, and the body size (total length, $L_{\mathrm{T}}$ ) of each individual was measured to the nearest $\mathrm{cm}$ on board. The stomachs were then removed and stored at $-20^{\circ} \mathrm{C}$ for subsequent stomach contents analysis. In addition to data on stomach contents and individual fish size, date, location (latitude and longitude), depth and temperature at surface and bottom were known for each haul.

\section{Quantification of stomach contents}

After thawing in the laboratory, the stomachs were opened and categorised as filled or empty, and only filled stomachs were retained for further examination. Clearly regurgitated stomachs were noted only among individuals of tusk Brosme brosme caught at 
the Miller platform, and the rest of the empty stomachs did not show any obvious signs of regurgitation (e.g. eversion of the stomach). In each filled stomach, the contents were sorted and identified to the lowest possible taxonomic level using a dissecting microscope. Parasitic nematodes, mucus, liquid and any freshly swallowed prey items due to post- or duringcapture feeding in the nets were excluded from the analysis. In a stomach sample, wet weight of each prey category was measured, and the composition of stomach contents was described as weight contribution of each prey.

\section{Data analysis}

The stomach contents data were analysed based on (1) aggregate stomach samples averaged per species per season for the Miller platform (saithe and 4 other species), (2) individual stomach samples of saithe and haddock for the Miller platform and (3) individual stomach samples of saithe for the IBTS survey and the Miller platform Q3. Multivariate analysis was conducted using PRIMER version 6 (Clarke \& Warwick 2001) to compare the structures and trends in the composition of prey items between (1) fish species taken from the Miller platform; (2) seasons (Q1 to Q4) or sampling depths (10, 50 and $103 \mathrm{~m})$ for both saithe and haddock taken from the Miller platform; and (3) spatially clustered groups for saithe taken from the IBTS survey and the Miller platform (Q3). Prior to the multivariate analysis, the weight of each prey category was square root transformed to downweight the influence of gravimetrically dominant prey items.

Aggregate stomach data for all fish species from the Miller platform (Q1 to Q4). For the data set obtained from the Miller platform, temporal variation in the composition of stomach contents for each fish species was first examined by plotting the percentage contribution of prey categories by weight against time. Subsequently, cluster analysis (group average linkage) was performed on a resemblance matrix (Bray-Curtis similarity index) of the transformed stomach contents data (aggregate). A non-metric multidimensional scaling (NMDS) was used to illustrate the degree of similarity between fish species across the sampling seasons on a 2D ordination plane based on the Bray-Curtis similarity measure. ANOSIM was performed to test for significant differences in diet compositions between the 3 most abundant fish species, namely saithe, haddock and cod, at the Miller platform. For this analysis, only Q2 to Q4 data were used because 2 of the 3 species did not occur in Q1. SIMPER analysis was performed to identify those species most responsible for the differences between species as well as the similarity within species.

Individual stomach data for saithe and haddock from the Miller platform (Q1 to Q4). Using individual stomach data, cluster analysis (group average linkage) was performed on a resemblance matrix (Bray-Curtis similarity index) for both saithe and haddock. Within each species, an NMDS was used to illustrate the degree of similarity between seasons (Q1 to Q4) across the sampling depths (surface: $10 \mathrm{~m}$; intermediate: $50 \mathrm{~m}$; bottom: $103 \mathrm{~m}$ ) on a 2D ordination plane. For each species, ANOSIM was performed to test for significant differences in the diet compositions between seasons or sampling depths. Where significant difference was found, RELATE routines were performed to examine temporal variation in the stomach contents structure in relation to each of the 3 biotic and abiotic factors: SIZE = body size (total length in $\mathrm{cm}$ ), S.TEMP = sea surface temperature $\left({ }^{\circ} \mathrm{C}\right)$ and B.TEMP $=$ bottom temperature $\left({ }^{\circ} \mathrm{C}\right)$. These variables were normalised to generate a resemblance matrix based on Euclidean distance for conducting BIO-ENV stepwise (BEST) analysis and principal component analysis (PCA). The BEST procedure was used to examine rank correlations between the multivariate patterns of the stomach contents and the environmental resemblance matrices to identify the subsets of environmental variables that best explained the overall pattern. PCA was used to identify the relative importance of those environmental variables that correlate with the multivariate pattern of the individual stomach data. Based on the results of the BEST procedures, those variables that significantly explained the temporal variation in the stomach contents structures were plotted using box plots.

Individual stomach data for saithe from the IBTS survey and the Miller platform (Q3). Using the data set obtained during the 2012 Q3 IBTS survey on the FRV 'Scotia', spatial variation in the saithe stomach contents was examined by plotting the percentage contribution of prey categories by weight against haul stations. A similarity profile test (SIMPROF) was performed on a resemblance matrix (Bray-Curtis similarity index) of the IBTS data to identify statistically significant spatial clusters of multivariate structure in the a priori unstructured set of samples (significance level: $\mathrm{p}<0.05)$. SIMPER analysis was then performed within and between the clusters identified by the SIMPROF test. In addition, RELATE routines 
were performed to examine potential differences in the stomach contents structure between the clusters in relation to each of the 3 aforementioned factors (SIZE, S.TEMP and B.TEMP) as well as 4 additional environmental variables: DEPTH = sampling depth $(\mathrm{m}) ;$ D.LAND $=$ distance to land $(\mathrm{km})$ : $[\log (x+1)$ transformed]; D.PLAT $=$ distance to nearest oil and gas platform $(\mathrm{km})$ : $[\log (x+1)$ transformed $]$; and N.PLAT $=$ number of platforms per ICES statistical rectangle (ind.): [ $\ln (x+1)$ transformed]. These variables were also normalised to generate a resemblance matrix based on Euclidean distance, and BEST analysis was performed to identify the subsets of environmental variables that best explained the overall pattern.

However, to examine the effects of the physical presence of offshore oil and gas platforms on the diet of saithe, it would be more desirable to conduct a survey at a gradient of distances, ideally ranging from $\sim 0.001$ to $>10 \mathrm{~km}$, from offshore structures in the study area. This is because the distances at which offshore artificial structures are likely to influence the abundance and/or the predominant movements of associated fish species (e.g. saithe and cod) would not normally exceed 0.1 to $5 \mathrm{~km}$ (e.g. Aabel et al. 1997, Løkkeborg et al. 2002, Soldal et al. 2002, Uglem et al. 2008, 2009). However, no fishery and survey vessels are currently permitted to operate closer than $0.5 \mathrm{~km}$ to any oil and gas platforms in the North Sea due to stringent safety regulations $(0.5 \mathrm{~km}$ safety zones). For this reason, during the 2012 Q3 IBTS survey, the FRV 'Scotia' operated mainly at locations farther than $10 \mathrm{~km}$ from any offshore structures and only on 2 occasions trawling was conducted at locations closer than $10 \mathrm{~km}$ from each of the nearest oil and gas platforms (2.4 and $7.5 \mathrm{~km})$. Thus, to compensate for the lack of saithe stomach data taken near the offshore structures $(<1 \mathrm{~km})$ in the IBTS survey, the Q3 data obtained from the Miller platform were combined with those from the IBTS survey. The same set of analyses (i.e. cluster, SIMPER, RELATE, BEST and PCA) were then repeated on the combined data to examine the degrees of consistency of the results derived from the 2 data sets (i.e. IBTS only vs. IBTS + Miller Q3). The bar plots and box plots were constructed using the $\mathrm{R}$ version 3.0.0 package (R Core Team 2013).

\section{RESULTS}

\section{Stomach contents of fishes at the Miller platform}

A total of 205 stomachs were collected from 6 identified fish species during the study period at the Miller platform (Table 1). The 6 species comprised

Table 1. Summary data for multi-seasonal fish sampling conducted at the Miller platform. Dep.code: deployment code (Miller [M], year (2010-2014), season [quarter Q1 winter - Q4 autumn]); Month: month of the year (1 = Jan, $10=$ Oct); N: total number of fish individuals caught per season; $N_{\mathrm{SF}}$ : number of stomachs filled; $L_{\mathrm{T}}$ : mean $\pm \mathrm{SD}$ body size (total length, $\mathrm{cm}$ ); $L R$ dab: long rough dab; -: no catch

\begin{tabular}{|c|c|c|c|c|c|c|c|c|c|c|c|c|c|c|c|c|c|c|c|}
\hline \multirow{2}{*}{$\begin{array}{l}\text { Year } \\
\text { Dep.code }\end{array}$} & \multirow[t]{2}{*}{ Month } & \multicolumn{3}{|c|}{ Saithe } & \multicolumn{3}{|c|}{ Haddock } & \multicolumn{3}{|c|}{ Cod } & \multicolumn{3}{|c|}{ Tusk } & \multicolumn{3}{|c|}{ Poor cod } & \multicolumn{3}{|c|}{ LR dab } \\
\hline & & $\mathrm{N}$ & $\mathrm{N}_{\mathrm{SF}}$ & $L_{\mathrm{T}}$ & $\mathrm{N}$ & $\mathrm{N}_{\mathrm{SF}}$ & $L_{\mathrm{T}}$ & $\mathrm{N}$ & $\mathrm{N}_{\mathrm{SF}}$ & $L_{\mathrm{T}}$ & $\mathrm{N}$ & $\mathrm{N}_{\mathrm{SF}}$ & $L_{\mathrm{T}}$ & $\mathrm{N}$ & $\mathrm{N}_{\mathrm{SF}}$ & $L_{\mathrm{T}}$ & $\mathrm{N}$ & $\mathrm{N}_{\mathrm{SF}}$ & $L_{\mathrm{T}}$ \\
\hline \multicolumn{20}{|l|}{2010} \\
\hline M10Q3 & 9 & 11 & 7 & $37.6 \pm 8.5$ & 9 & 4 & $40.9 \pm 3.6$ & - & - & - & - & - & - & - & - & - & - & - & - \\
\hline M10Q4 & 10 & 13 & 12 & $43.1 \pm 12.6$ & 11 & 5 & $44.9 \pm 3.4$ & - & - & - & 1 & 0 & 75 & 1 & 0 & 19 & - & - & - \\
\hline \multicolumn{20}{|c|}{ 20 } \\
\hline M11Q1 & 1 & 38 & 6 & $58.3 \pm 4.7$ & - & - & - & - & - & - & - & - & - & - & - & - & - & - & - \\
\hline M11Q2 & 4 & 7 & 3 & $50.3 \pm 9.9$ & 1 & 1 & 44 & 1 & 0 & 75 & 1 & 0 & 54 & 1 & 1 & 30 & - & - & - \\
\hline M11Q3 & 7 & 14 & 13 & $56.9 \pm 7.0$ & 8 & 5 & $40.9 \pm 3.5$ & 2 & 1 & $51.5 \pm 14.8$ & - & - & - & - & - & - & - & - & - \\
\hline M11Q4 & 10 & 6 & 6 & $46.2 \pm 7.6$ & 5 & 3 & $39.8 \pm 4.3$ & 2 & 2 & $59.0 \pm 15.6$ & - & - & - & - & - & - & - & - & - \\
\hline \multicolumn{20}{|l|}{2012} \\
\hline M12Q1 & 1 & 14 & 9 & $47.1 \pm 7.3$ & - & - & - & - & - & - & - & - & - & - & - & - & - & - & - \\
\hline M12Q2 & 4 & 3 & 3 & $43.7 \pm 1.5$ & - & - & - & - & - & - & - & - & - & 1 & 0 & 29 & 1 & 0 & 17 \\
\hline M12Q3 & 7 & 3 & 3 & $44.0 \pm 5.2$ & 2 & 2 & $46.5 \pm 0.7$ & - & - & - & 1 & 0 & 60 & - & - & - & - & - & - \\
\hline M12Q4 & - & & & & & & (No S & $m p$ & ling & undertakes & & & & & & & & & \\
\hline \multicolumn{20}{|c|}{ (1) } \\
\hline M13Q1 & 1 & 5 & 5 & $41.0 \pm 6.9$ & - & - & - & - & - & - & - & - & - & - & - & - & - & - & - \\
\hline M13Q2 & 4 & 4 & 4 & $44.5 \pm 2.9$ & 5 & 2 & $40.7 \pm 2.1$ & 4 & 3 & $48.0 \pm 22.8$ & - & - & - & 1 & 1 & 23 & - & - & - \\
\hline M13Q3 & 8 & 8 & 5 & $50.9 \pm 3.8$ & - & - & - & - & - & - & 3 & 3 & $68.0 \pm 15.1$ & - & - & - & - & - & - \\
\hline M13Q4 & 10 & 15 & 12 & $46.7 \pm 3.5$ & - & - & - & - & - & - & 1 & 0 & 63 & - & - & - & - & - & - \\
\hline \multicolumn{20}{|l|}{2014} \\
\hline M14Q1 & 1 & 2 & 2 & $43.5 \pm 2.1$ & - & - & - & - & - & - & - & - & - & - & - & - & - & - & - \\
\hline
\end{tabular}




\begin{tabular}{|c|c|c|c|c|c|c|c|c|c|}
\hline & markii & $\mathbb{Q}$ & C. harengus & $\square$ & Euphausiacea & $\square$ & Ophiuroidea & 四 & Bryozoa \\
\hline & G. argenteus & $\square$ & Ammodytidae & $\square$ & Caridea & 四 & Echinoidea & $\square$ & Hydrozoa \\
\hline & S. s & 四 & Gok & 口 & ida & $\square$ & Bivalvia/Gastropoda & $\square$ & Un \\
\hline & & $\square$ & fied fish & 巴 & Cirripedia & $\mathbb{Q}$ & Cephalopoda & $\square$ & tents \\
\hline & M. merlangus & $\square$ & Polychaete & $\mathbb{Q}$ & Anomura/Brachyura & $\square$ & Actiniaria & $\square$ & No data \\
\hline
\end{tabular}

(a)

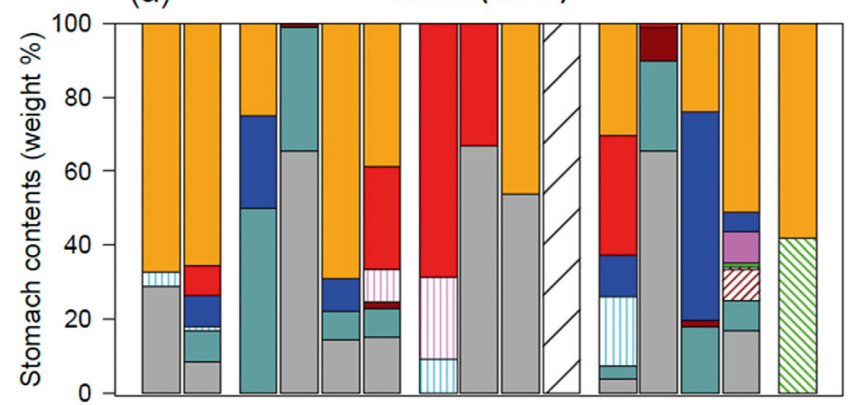

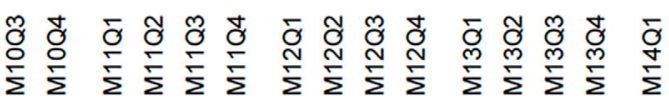

(c)

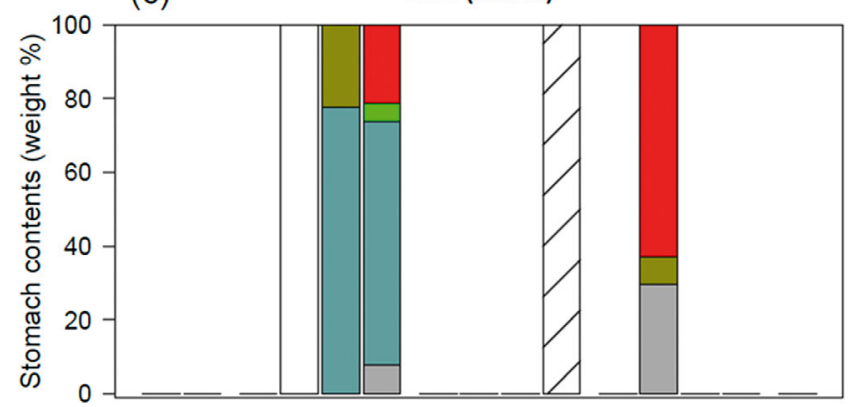

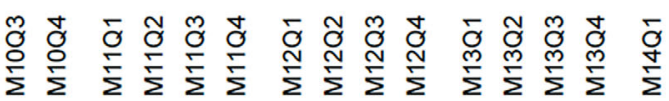

(e)

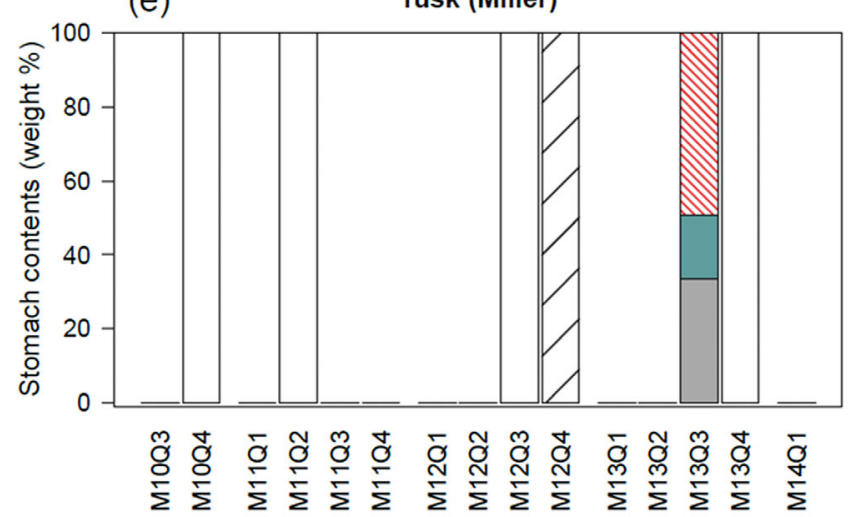

(b)

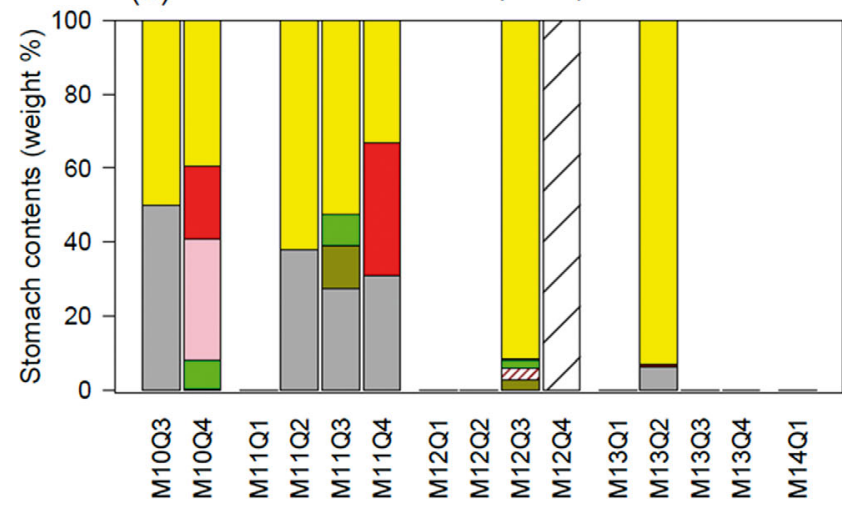

(d)

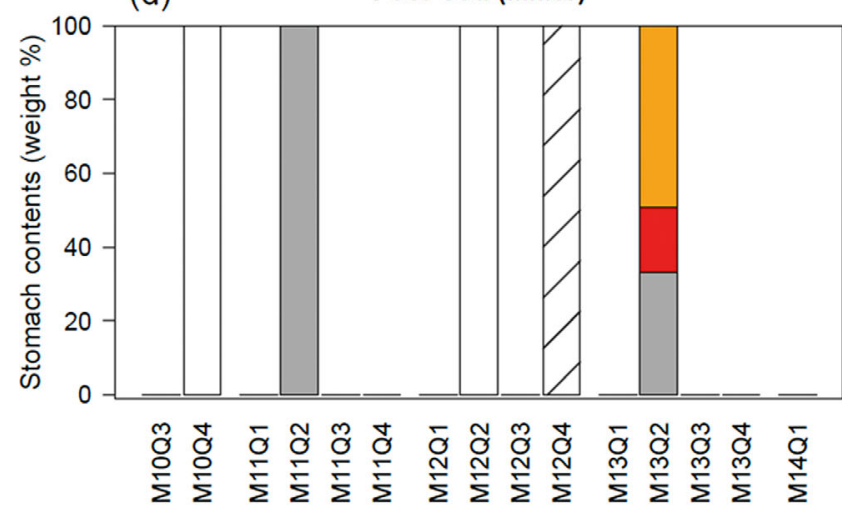

(f)

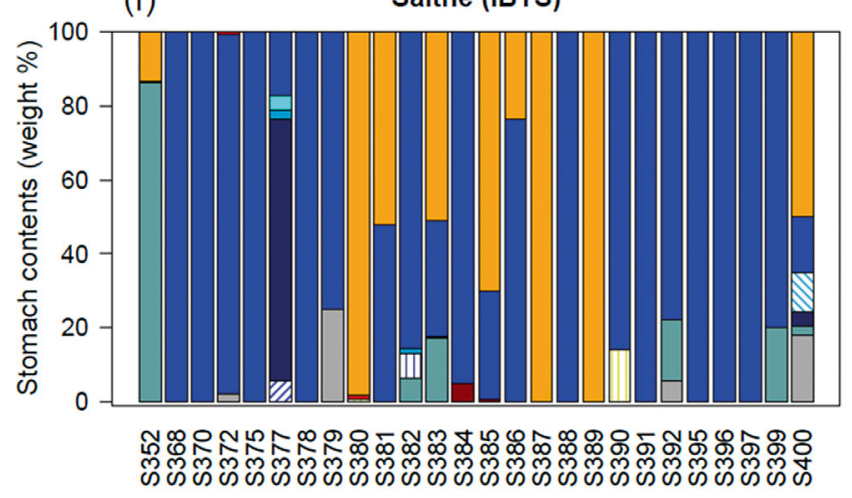

Fig. 2. Changes in the mean percentage weight composition of stomach contents for each fish species caught at the Miller platform, (a) saithe, (b) haddock, (c) cod, (d) poor cod and (e) tusk, and for (f) saithe sampled in the International Bottom Trawl Survey (IBTS) on the FRV 'Scotia'. Coding of stations and seasons as in Fig. 1, Tables 1 \& 7. Abbreviated genus name:

T.: Trisopterus; G.: Gadiculus; S.: Scomber; A.: Argentina; M.: Merlangius; C.: Clupea 
saithe Pollachius virens $(69.8 \%)$, haddock Melanogrammus aeglefinus (20.0\%), cod Gadus morhua $(4.4 \%)$ and poor cod Trisopterus minutus $(2.0 \%)$, which all belong to the family Gadidae; 1 species of Lotidae, tusk Brosme brosme (3.4\%); and 1 species of Pleuronectidae, long rough dab Hippoglossoides platessoides $(0.5 \%)$. Long rough dab was caught only once in Q2 2012, and its stomach was empty.

The diet of saithe was mainly characterised by high proportions of euphausiids (Euphausiacea), followed by Norway pout $T$. esmarkii, caridean shrimps (Caridea) and fish other than T. esmarkii and gobies (Gobiidae) (Fig. 2a). The importance of euphausiids as prey items remained essentially unchanged across seasons throughout the study period except for the spring months (Q2), where complete absence of euphausiids from saithe stomach contents was noted. The relative importance of both $T$. esmarkii and caridean shrimps changed markedly between seasons as well as years. Occasional occurrences of bryozoans (Bryozoa) and hydrozoans (Hydrozoa) in saithe stomachs were also noted in the autumn (Q4) and winter (Q1) seasons (Fig. 2a). In contrast, haddock fed mainly on ophiuroids (Ophiuroidea) (Fig. 2b). Caridean shrimps were also consumed in high proportions at times, and other important prey for haddock included polychaetes (Polychaeta), bivalves (Bivalvia, e.g. Mytilus sp.), gastropods (Gastropoda) and actiniarians (Actiniaria) (Fig. 2b). Cod predominantly fed on fish other than $T$. esmarkii and gobies in summer (Q3) and autumn (Q4) seasons in 2011 but on caridean shrimps in spring (Q2) 2013 (Fig. 2c). Although the sample size was limited, poor cod was found to consume euphausiids and caridean shrimps (Fig. 2d), whereas tusk was found to feed on brachyuran crabs (Brachyura), hermit crabs (Anomura) and fish other than $T$. esmarkii and gobies (Fig. 2e) at the Miller platform.

The results of ANOSIM showed that stomach contents were significantly different between the 3 most characteristic species, saithe, haddock and cod, for Q2 to Q4 at the Miller platform (Table 2). Pairwise comparisons indicated that the diet of saithe was significantly different from that of both haddock and cod, and the diet of haddock was also significantly different from that of cod (Table 2). The NMDS plot also illustrated the clear separation of the structures of the stomach contents between the fish species (Fig. 3a). The SIMPER analysis showed average similarities of the stomach contents within saithe, haddock and cod for Q2 to Q4, respectively (Fig. 4a). Euphausiids were the prey items which contributed predominantly to the average similarity within saithe, whereas ophiuroids were the sole prey taxon that was responsible for the similarity within haddock. The average dissimilarity level between the stomach contents of saithe and haddock was the highest, which was largely accounted for by the exclusive occurrences of ophiuroids and euphausiids in the diets of haddock and saithe, respectively (Table 3 ). Haddock and cod showed the second highest dissimilarity, and the exclusive occurrence of ophiuroids in haddock diets as well as the very high consumption of fish other than $T$. esmarkii and gobies by cod altogether contributed to the majority of the dissimilarity observed (Table 3). Saithe and cod showed the least average

Table 2. ANOSIM results for comparing variation in the structures of fish stomach contents in terms of species (saithe, haddock and cod); season (Quarter [Q] 1 to Q4); and sampling depth (surface, $\mathrm{S}: 10 \mathrm{~m}$ i intermediate, M: $50 \mathrm{~m}$; bottom, B: $103 \mathrm{~m}$ ). Subscripted numbers in parentheses indicate sample size. ns: not significant

\begin{tabular}{|c|c|c|c|c|}
\hline Data & Factor & Global/pairwise test & $\mathrm{t} \quad \mathrm{R}$ & $\mathrm{p}$ \\
\hline \multirow{4}{*}{$\begin{array}{l}\text { Three fishes } \\
\text { stomach contents } \\
\text { (aggregate data } \\
\text { for Q2-Q4) }\end{array}$} & \multirow{4}{*}{$\begin{array}{l}\text { Species } \\
\text { (Saithe }_{(10),} \\
\left.\text { Haddock }_{(7)}, \operatorname{Cod}_{(3)}\right)\end{array}$} & Global & 0.663 & $<0.001$ \\
\hline & & Saithe $\times$ Haddock & 0.786 & $<0.001$ \\
\hline & & Saithe $\times$ Cod & 0.360 & $<0.05$ \\
\hline & & Haddock $\times$ Cod & 0.766 & $<0.01$ \\
\hline \multirow{11}{*}{$\begin{array}{l}\text { Saithe } \\
\text { stomach contents } \\
\text { (individual } \\
\text { data) }\end{array}$} & \multirow{7}{*}{$\begin{array}{l}\text { Season } \\
\left(\mathrm{Q} 1_{(20)}, \mathrm{Q} 2_{(8)},\right. \\
\left.\mathrm{Q} 3_{(24)}, \mathrm{Q} 4_{(27)}\right)\end{array}$} & Global & 0.209 & $<0.001$ \\
\hline & & $\mathrm{Q} 1 \times \mathrm{Q} 2$ & 0.163 & $<0.05$ \\
\hline & & $\mathrm{Q} 1 \times \mathrm{Q} 3$ & 0.286 & $<0.001$ \\
\hline & & $\mathrm{Q} 1 \times \mathrm{Q} 4$ & 0.190 & $<0.01$ \\
\hline & & $\mathrm{Q} 2 \times \mathrm{Q} 3$ & 0.608 & $<0.001$ \\
\hline & & $\mathrm{Q} 2 \times \mathrm{Q} 4$ & 0.415 & $<0.001$ \\
\hline & & $\mathrm{Q} 3 \times \mathrm{Q} 4$ & -0.012 & ns \\
\hline & Depth & Global & -0.016 & ns \\
\hline & $\left(\mathrm{S}_{(6)}, \mathrm{M}_{(15)}, \mathrm{B}_{(58)}\right)$ & $\mathrm{S} \times \mathrm{M}$ & 0.326 & $<0.05$ \\
\hline & & $\mathrm{S} \times \mathrm{B}$ & 0.103 & ns \\
\hline & & $\mathrm{M} \times \mathrm{B}$ & -0.075 & ns \\
\hline \multirow{5}{*}{$\begin{array}{l}\text { Haddock } \\
\text { stomach contents } \\
\text { (individual } \\
\text { data) }\end{array}$} & \multirow{4}{*}{$\begin{array}{l}\text { Season } \\
\left(\mathrm{Q} 2_{(3)}, \mathrm{Q} 3_{(8)}, \mathrm{Q} 4_{(8)}\right)\end{array}$} & Global & 0.073 & ns \\
\hline & & $\mathrm{Q} 2 \times \mathrm{Q} 3$ & -0.212 & ns \\
\hline & & $\mathrm{Q} 2 \times \mathrm{Q} 4$ & 0.011 & $\mathrm{~ns}$ \\
\hline & & $\mathrm{Q} 3 \times \mathrm{Q} 4$ & 0.178 & $<0.05$ \\
\hline & $\begin{array}{l}\text { Depth } \\
\left(\mathrm{M}_{(5)}, \mathrm{B}_{(14)}\right)\end{array}$ & Global & -0.167 & ns \\
\hline
\end{tabular}


(a) All species (Miller)

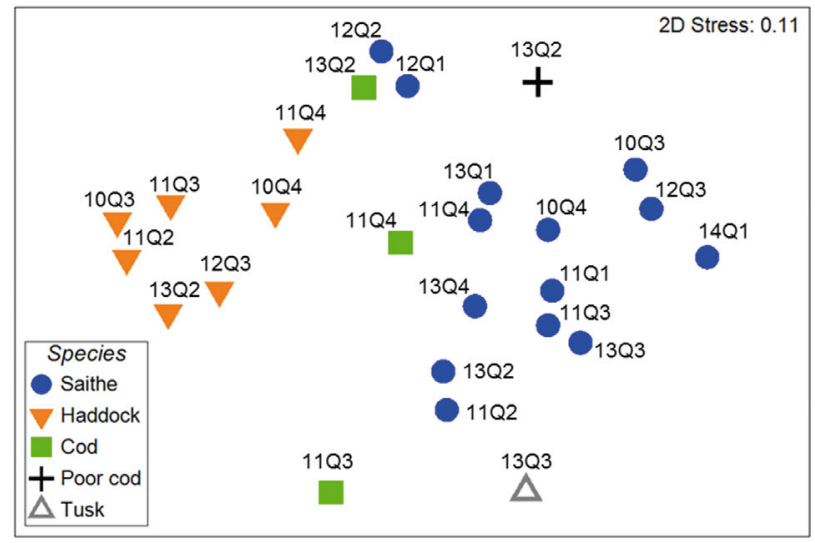

(b) Saithe (Miller)

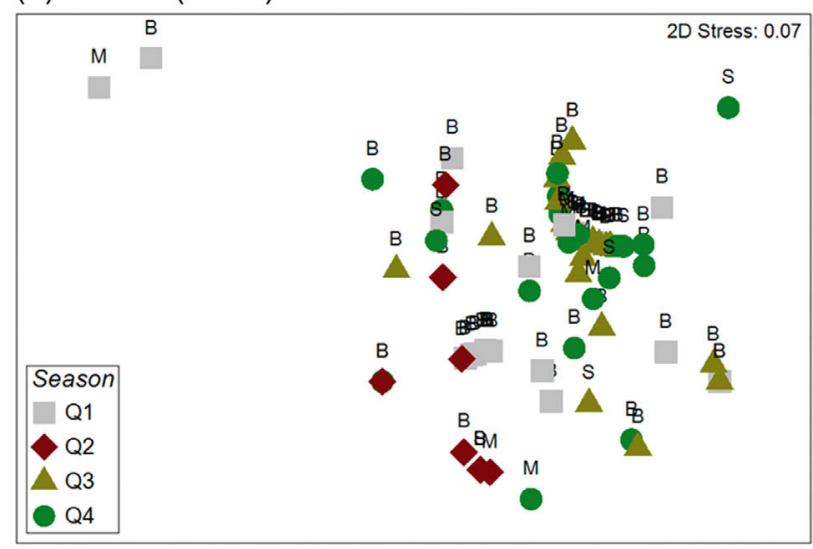

\section{(c) Haddock (Miller)}

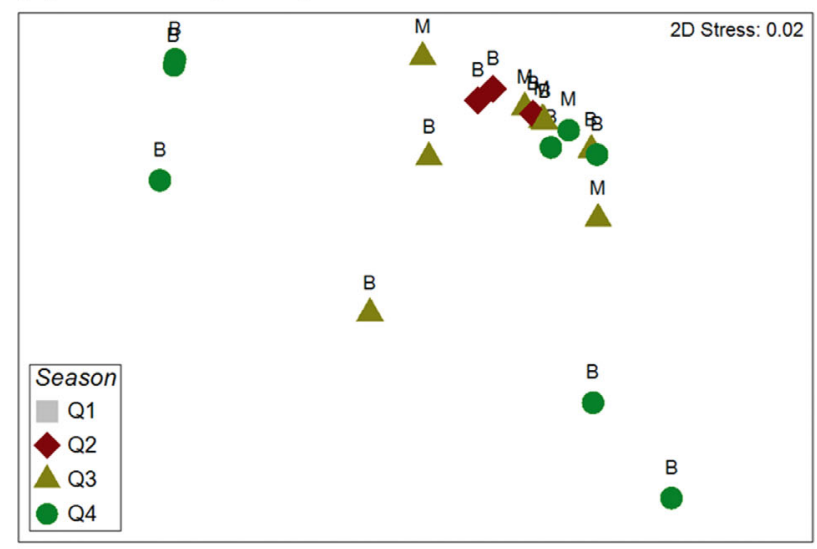

Fig. 3. Result of the multivariate analysis of fish stomach contents obtained at the Miller platform for (a) all fish species based on aggregate data, (b) saithe based on individual data and (c) haddock based on individual data, showing non-metric multidimensional scaling (NMDS) ordination based on square root transformation and Bray-Curtis similarity. Coding of deployment seasons and depths as in Tables 1 \& 2

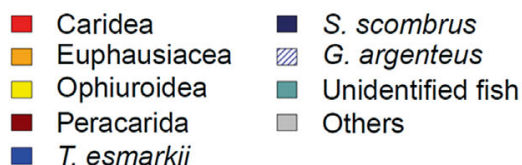

(a)

Fish stomach contents (Miller)

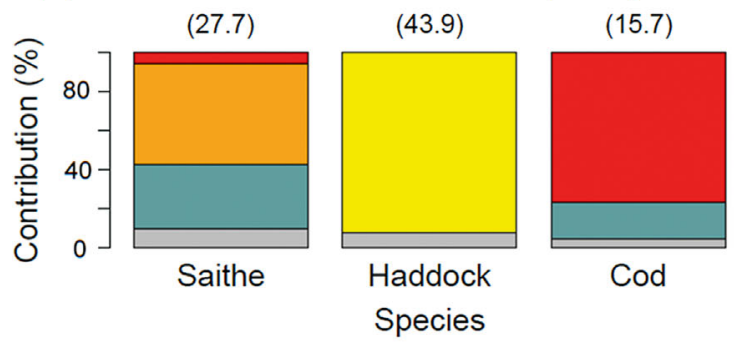

(b) Saithe stomach contents (Miller)

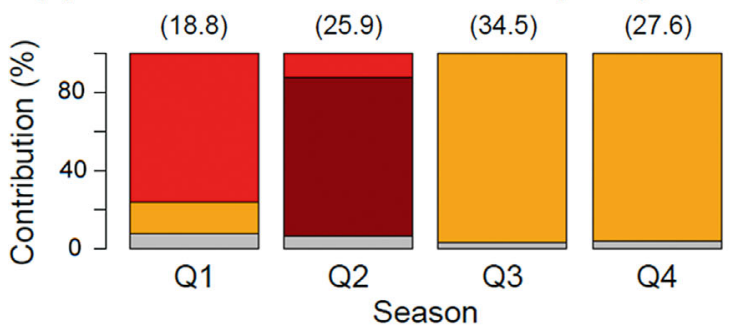

(c) Saithe stomach contents (IBTS)

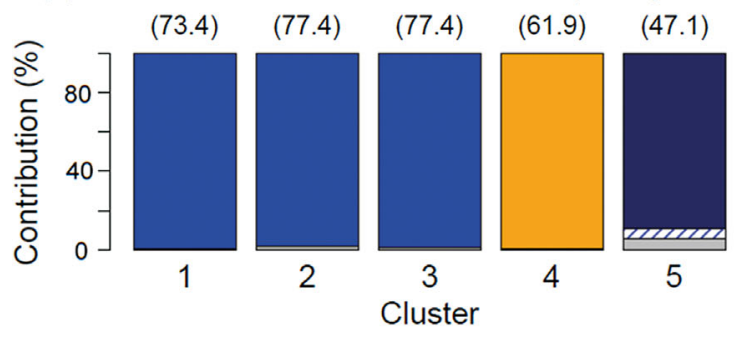

(d) Saithe stomach contents (IBTS + Miller Q3)

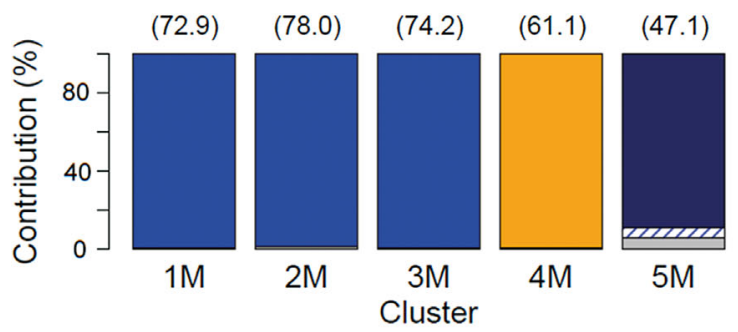

Fig. 4. Percentage contributions of prey items which accounted for most of the similarity ( $>90 \%$ ) within the groups based on the SIMPER analysis: (a) fish stomach contents sampled at the Miller platform; (b) saithe stomach contents sampled at the Miller platform across seasons; (c) saithe stomach contents sampled across the North Sea (International Bottom Trawl Survey [IBTS]); (d) saithe stomach contents sampled across the North Sea including the Miller platform Q3 (IBTS + Miller Q3). Average similarity within each group is shown at the top in parentheses (\%). Abbreviated genus names as in Fig. 2, seasons as in Table 1 
Table 3. Analysis of stomach contents of saithe, haddock and cod. Breakdown of average dissimilarities between fish species, with percentage contributions of prey items which accounted for most $(>90 \%)$ of those values based on SIMPER analysis. Contrib.: contribution; Cum. contrib.: cumulative contribution; Av. diss.: average dissimilarity. Relative stomach contents are square root transformed data in weight $(\mathrm{g})$

\begin{tabular}{|c|c|c|c|c|c|}
\hline \multirow[t]{2}{*}{ Prey item } & \multicolumn{2}{|c|}{$\begin{array}{c}\text { Relative } \\
\text { stomach contents }\end{array}$} & \multirow{2}{*}{$\begin{array}{l}\text { Contrib. } \\
\qquad(\%)\end{array}$} & \multirow{2}{*}{$\begin{array}{c}\text { Cum. } \\
\text { contrib. } \\
(\%)\end{array}$} & \multirow{2}{*}{$\begin{array}{r}\text { Av. } \\
\text { diss } \\
(\%)\end{array}$} \\
\hline & Saithe & Haddock & & & \\
\hline Ophiuroidea & 0.01 & 2.11 & 43.7 & 43.7 & \\
\hline Euphausiacea & 0.56 & 0.00 & 12.3 & 55.9 & \\
\hline Unidentified fish & 0.49 & 0.01 & 10.8 & 66.7 & \\
\hline Trisopterus esmarkii & i $\quad 0.48$ & 0.00 & 7.4 & 74.2 & \\
\hline Caridea & 0.10 & 0.21 & 6.4 & 80.5 & \\
\hline Bivalvia/Gastropoda & 0.03 & 0.26 & 5.0 & 85.5 & \\
\hline Actiniaria & 0.00 & 0.18 & 3.5 & 89.0 & \\
\hline \multirow[t]{2}{*}{ Polychaete } & 0.00 & 0.15 & 2.6 & 91.6 & \\
\hline & Saithe & Cod & & & 85.1 \\
\hline Unidentified fish & 0.49 & 3.31 & 34.5 & 34.5 & \\
\hline Euphausiacea & 0.56 & 0.00 & 15.2 & 49.7 & \\
\hline Polychaete & 0.00 & 1.70 & 15.1 & 64.9 & \\
\hline Caridea & 0.10 & 0.40 & 14.2 & 79.1 & \\
\hline T. esmarkii & 0.48 & 0.00 & 8.3 & 87.4 & \\
\hline \multirow{2}{*}{ Bivalvia/Gastropoda } & 0.03 & 0.12 & 4.4 & 91.8 & \\
\hline & Haddock & Cod & & & 89.9 \\
\hline Ophiuroidea & 2.11 & 0.00 & 39.9 & 39.9 & \\
\hline Unidentified fish & 0.01 & 3.31 & 26.1 & 66.0 & \\
\hline Polychaete & 0.15 & 1.70 & 13.6 & 79.6 & \\
\hline Caridea & 0.21 & 0.40 & 9.6 & 89.2 & \\
\hline Bivalvia/Gastropoda & 0.26 & 0.12 & 5.5 & 94.6 & \\
\hline
\end{tabular}

dissimilarity, with the majority of dissimilarity accounted for by the higher proportions of fish other than T. esmarkii and gobies and the total absence of euphausiids as well as the higher proportion of polychaetes in the diet of cod (Table 3).

\section{Stomach contents of saithe and haddock at the Miller platform}

Using individual stomach data of both saithe and haddock taken from the Miller platform, the ANOSIM revealed that the stomach contents were significantly different between seasons only for saithe, and there was no significant difference between sampling depths for both saithe and haddock (Table 2). Pairwise comparisons indicated that the diet of saithe was significantly different between any combination of seasons except for between Q3 and Q4 (Table 2). The R statistic in the ANOSIM also showed that the degree of difference was the largest between Q2 and Q3, followed by Q2 and Q4, when compared with the relatively small differences between Q1 and the rest of the seasons, Q2 to Q4 (Table 2). These trends were also illustrated in the NMDS plots for both saithe and haddock (Fig. 3b,c). With reference to the significant seasonal variation found in the saithe diet, the average similarities within the stomach contents of saithe for Q1 to Q4 are shown in Fig. 4b. Caridean shrimps and peracarids (e.g. Amphipoda, Isopoda) were the prey items which contributed predominantly to the average similarity within Q1 and Q2, respectively, whereas euphausiids were the sole prey taxon that was responsible for the similarity within Q3 and Q4 (Fig. 4b). The average dissimilarity levels between the stomach contents of saithe in Q2 and the rest of the seasons (Q1, Q3 and Q4) were the highest, which was largely accounted for by the occurrence of peracarids and the total absence of euphausiids in the diets of saithe in Q2 (Table 4). Q1 and Q3 to Q4 showed the second highest levels of dissimilarity, and the much higher proportions of caridean shrimps but the lower occurrence of euphausiids in Q1 altogether contributed to the majority of the dissimilarity observed (Table 4). Q3 and Q4 showed the least average dissimilarity, with the majority of dissimilarity accounted for by the higher proportion of $T$. esmarkii but the lower proportion of euphausiids in the diet of saithe in Q3 (Table 4).

When the environmental variables were examined individually, the RELATE tests showed that S.TEMP had the highest correlation with the saithe stomach contents resemblance matrix, followed by B.TEMP (Table 5). SIZE was not significantly correlated with the stomach contents resemblance at the Miller platform (Table 5). The BEST analysis, however, showed that the 5 best combinations of environmental variables, which generated the highest rank correlation with the multivariate data of the saithe diet, were combinations of the 3 variables including SIZE (Table 6). The combination of S.TEMP and B.TEMP produced the highest correlation, followed by the combination of S.TEMP, B.TEMP and SIZE (Table 6). The PCA of environmental variables also showed the influence of these variables, which explained $72.7 \%$ of the total variance (principal component [PC] axis 1: $41.9 \%$ and PC axis 2: $30.8 \%$ ) (Fig. 5). The 3 variables (i.e. S.TEMP, B. TEMP and SIZE) were plotted across seasons using box plots (Fig. 6). Temperatures 
Table 4. Analysis of stomach contents of saithe in relation to seasons (Q1 winter - Q4 autumn). Breakdown of average dissimilarities between fish species, with percentage contributions of prey items which accounted for most ( $>90 \%$ ) of those values based on SIMPER analysis. Contrib.: contribution; Cum. contrib.: cumulative contribution; Av. diss.: average dissimilarity. Relative stomach contents are square root transformed data in weight $(\mathrm{g})$

\begin{tabular}{|c|c|c|c|c|c|}
\hline \multirow[t]{2}{*}{ Prey item } & \multicolumn{2}{|c|}{$\begin{array}{c}\text { Relative } \\
\text { stomach contents }\end{array}$} & \multirow{2}{*}{$\begin{array}{c}\text { Contrib. } \\
\qquad(\%)\end{array}$} & \multirow{2}{*}{$\begin{array}{c}\text { Cum. } \\
\text { contrib. } \\
(\%)\end{array}$} & \multirow{2}{*}{$\begin{array}{r}\text { Av. } \\
\text { diss } \\
(\%)\end{array}$} \\
\hline & Q1 & Q2 & & & \\
\hline Caridea & 0.39 & 0.10 & 30.8 & 30.8 & \\
\hline Unidentified fish & 0.12 & 0.33 & 20.6 & 51.4 & \\
\hline Peracarida & 0.00 & 0.20 & 17.3 & 68.7 & \\
\hline Euphausiacea & 0.22 & 0.00 & 13.9 & 82.6 & \\
\hline Gobiidae & 0.07 & 0.00 & 5.3 & 87.9 & \\
\hline \multirow[t]{2}{*}{ Trisopterus esmarkii } & 0.08 & 0.00 & 4.7 & 92.6 & \\
\hline & Q1 & Q3 & & & 87.4 \\
\hline Euphausiacea & 0.22 & 0.61 & 36.9 & 36.9 & \\
\hline Caridea & 0.39 & 0.00 & 24.0 & 60.9 & \\
\hline T. esmarkii & 0.08 & 0.41 & 14.2 & 75.1 & \\
\hline Unidentified fish & 0.12 & 0.31 & 12.8 & 87.8 & \\
\hline \multirow[t]{2}{*}{ Gobiidae } & 0.07 & 0.02 & 5.3 & 93.1 & \\
\hline & Q1 & Q4 & & & 86.0 \\
\hline Euphausiacea & 0.22 & 0.73 & 37.6 & 37.6 & \\
\hline Caridea & 0.39 & 0.07 & 22.6 & 60.2 & \\
\hline Unidentified fish & 0.12 & 0.15 & 11.9 & 72.1 & \\
\hline T. esmarkii & 0.08 & 0.23 & 8.7 & 80.8 & \\
\hline Gobiidae & 0.07 & 0.03 & 4.7 & 85.4 & \\
\hline Bryozoa & 0.03 & 0.03 & 4.0 & 89.4 & \\
\hline \multirow[t]{2}{*}{ Peracarida } & 0.00 & 0.06 & 3.2 & 92.6 & \\
\hline & Q2 & Q3 & & & 98.2 \\
\hline Euphausiacea & 0.00 & 0.61 & 42.6 & 42.6 & \\
\hline Unidentified fish & 0.33 & 0.31 & 18.9 & 61.5 & \\
\hline Peracarida & 0.20 & 0.02 & 16.6 & 78.1 & \\
\hline \multirow[t]{2}{*}{ T. esmarkii } & 0.00 & 0.41 & 12.1 & 90.2 & \\
\hline & Q2 & Q4 & & & 94.9 \\
\hline Euphausiacea & 0.00 & 0.73 & 42.6 & 42.6 & \\
\hline Unidentified fish & 0.33 & 0.15 & 18.0 & 60.6 & \\
\hline Peracarida & 0.20 & 0.06 & 16.2 & 76.8 & \\
\hline Caridea & 0.10 & 0.07 & 10.7 & 87.5 & \\
\hline \multirow[t]{2}{*}{ T. esmarkii } & 0.00 & 0.23 & 5.5 & 93.0 & \\
\hline & Q3 & Q4 & & & 68.7 \\
\hline Euphausiacea & 0.61 & 0.73 & 45.4 & 45.4 & \\
\hline T. esmarkii & 0.41 & 0.23 & 19.0 & 64.5 & \\
\hline Unidentified fish & 0.31 & 0.15 & 15.6 & 80.0 & \\
\hline Caridea & 0.00 & 0.07 & 5.5 & 85.5 & \\
\hline Peracarida & 0.02 & 0.06 & 4.7 & 90.3 & \\
\hline
\end{tabular}

in Q2 were the coldest at both surface and bottom waters, and they varied significantly between seasons except for between Q3 and Q4 in B.TEMP (Fig. $6 a, b)$. Sample numbers were relatively low in Q2 at the Miller platform (Fig. 6, Table 1), and body size distribution also showed a relatively narrow range compared to the other seasons (Fig. 6c).

\section{Stomach contents of saithe across the North Sea}

During the 2012 Q3 IBTS on the FRV 'Scotia', saithe was present at 32 stations out of 85 ICES statistical rectangles (Fig. 1), and 334 individuals of saithe were caught in the GOV trawl hauls across the North Sea, of which 195 individuals were extracted for stomach contents analysis in this study (Table 7). The diet of saithe from the trawl survey was mainly characterised by higher proportions of $T$. esmarkii across the sampling stations (Fig. 2f) in comparison with the trends observed at the Miller platform (Fig. 2a). Approximately a quarter of the sampling stations, however, exhibited high proportions of euphausiids. The relative importance of the 2 dominant prey items, namely $T$. esmarkii and euphausiids, varied markedly depending on the location of the sampling stations (Figs. 1 \& 2f).

Within the IBTS samples, 5 significantly different spatial clusters were identified based on a SIMPROF analysis (Fig. 7a). Clusters 2, 3 and 5 comprised only $13(8.7 \%), 8(5.4 \%)$ and 7 $(4.7 \%)$ individual samples, respectively. The rest of the samples were grouped into either Cluster 1 (77 samples, 51.7\%) or Cluster 4 (44 samples, $29.5 \%$ ). Based on the SIMPER analysis, Clusters 1, 2 and 3 all showed an average similarity of over $70 \%$, all of which were solely explained by the presence of $T$. esmarkii in their diets (Fig. 4c). As for Clusters 4 and 5, euphausiids were the prey items which contributed solely to the average similarity within Cluster 4, whereas mackerel Scomber scombrus was the predominant prey taxon that was responsible for the similarity within Cluster 5 (Fig. 4c). Although the IBTS survey was conducted in Q3, Cluster 4 was the only spatial group which showed similar saithe stomach contents sampled in Q3 at the Miller platform (Fig. $4 \mathrm{~b}, \mathrm{c}$ ). Clusters 1 and 2 showed the least average dissimilarity, with most of the dissimilarity accounted for by higher proportions of $T$. esmarkii found in the diet of saithe individuals in Cluster 2 (Table 8). In contrast, the average dissimilarity levels between Cluster 5 and the rest of the cluster groups were the highest, the majority of which were accounted for by the exclusive occurrence of $S$. scombrus in the diet of saithe individuals in Cluster 5 (Table 8). Cluster 3 was also dissimilar to Clusters 1, 2 and 4 relatively high percentages, the majority of 
Table 5. Analysis of stomach contents of saithe. Results of RELATE tests, showing Spearman's rank correlation coefficients ( $\rho$ ) between individual variables and saithe stomach contents structure for the Miller platform (Quarter [Q] 1 to Q4, see Table 1), International Bottom Trawl Survey (IBTS) (Q3) and IBTS + Miller (Q3). ns: not significant; -: not included

\begin{tabular}{|c|c|c|c|c|c|c|c|}
\hline \multirow[t]{2}{*}{ Variable code } & \multirow[t]{2}{*}{ Description } & \multicolumn{2}{|c|}{ Miller (Q1-Q4) } & \multicolumn{2}{|c|}{ IBTS (Q3) } & \multicolumn{2}{|c|}{ IBTS + Miller (Q3) } \\
\hline & & $\begin{array}{l}\text { Correlation } \\
(\rho)\end{array}$ & $\mathrm{p}$ & $\begin{array}{l}\text { Correlation } \\
(\rho)\end{array}$ & $\mathrm{p}$ & $\begin{array}{l}\text { Correlation } \\
(\rho)\end{array}$ & $\mathrm{p}$ \\
\hline S.TEMP & Sea surface temperature $\left({ }^{\circ} \mathrm{C}\right)$ & 0.264 & $<0.01$ & 0.005 & ns & 0.019 & ns \\
\hline B.TEMP & Sea bottom temperature $\left({ }^{\circ} \mathrm{C}\right)$ & 0.233 & $<0.01$ & 0.006 & ns & 0.031 & ns \\
\hline SIZE & Body size (total length, $\mathrm{cm}$ ) & 0.044 & ns & 0.155 & $<0.01$ & 0.164 & $<0.01$ \\
\hline DEPTH & Water depth (m) & - & - & 0.099 & $<0.05$ & 0.113 & $<0.01$ \\
\hline D.PLAT & $\begin{array}{l}\text { Distance to the nearest oil and } \\
\text { gas platform }(\mathrm{km})\end{array}$ & - & - & 0.010 & ns & 0.126 & $<0.01$ \\
\hline N.PLAT & $\begin{array}{l}\text { Number of platforms per ICES } \\
\text { statistical rectangle }\end{array}$ & - & - & -0.002 & ns & 0.069 & $<0.01$ \\
\hline D.LAND & Distance to the nearest land $(\mathrm{km})$ & - & - & -0.016 & ns & 0.042 & $<0.01$ \\
\hline
\end{tabular}

which was accounted for by the differences in the relative proportions of T. esmarkii in Cluster 3 in comparison with the rest of the clusters (Table 8). Finally, the average dissimilarity between Clusters 1 and 4 was largely accounted for by the much lower proportions of euphausiids and much higher occurrences of T. esmarkii in the diet of saithe in Cluster 1 when compared with Cluster 4 (Table 8).

Table 6. Results of BIO-ENV stepwise analysis, showing the 5 best combinations of environmental variables that generated the highest Spearman's rank correlations ( $\rho)$ with saithe stomach contents structure for the Miller platform (seasons Quarter [Q] 1 to Q4, see Table 1), International Bottom Trawl Survey (IBTS) (Q3) and IBTS + Miller (Q3). Coding of environmental variables as in Table 5

\begin{tabular}{|lcc|}
\hline Subset of variables & $\begin{array}{c}\text { Correlation } \\
(\rho)\end{array}$ & $\mathrm{p}$ \\
\hline Miller (Q1-Q4) & & \\
S.TEMP + B.TEMP & 0.318 & $<0.01$ \\
S.TEMP + B.TEMP + SIZE & 0.298 & $<0.01$ \\
S.TEMP & 0.264 & $<0.01$ \\
B.TEMP & 0.233 & $<0.01$ \\
S.TEMP + SIZE & 0.225 & $<0.01$ \\
IBTS (Q3) & & \\
SIZE + DEPTH + N.PLAT & 0.164 & $<0.01$ \\
SIZE & 0.155 & $<0.01$ \\
SIZE + DEPTH & 0.155 & $<0.01$ \\
SIZE + N.PLAT & 0.153 & $<0.01$ \\
SIZE + DEPTH + D.PLAT & 0.145 & $<0.01$ \\
IBTS + Miller (Q3) & & \\
SIZE + D.PLAT & & \\
SIZE + D.PLAT + DEPTH & 0.220 & $<0.01$ \\
SIZE + D.PLAT + DEPTH + N.PLAT & 0.216 & $<0.01$ \\
SIZE + D.PLAT + N.PLAT & 0.212 & $<0.01$ \\
SIZE + D.PLAT + S.TEMP & 0.196 & $<0.01$ \\
& & \\
\hline
\end{tabular}

The RELATE tests showed that only SIZE and water depth (DEPTH) were significantly correlated with the saithe stomach contents resemblance matrix individually (Table 5). The BEST analysis, however, revealed that the 5 best subsets of environmental variables were combinations of SIZE and DEPTH as well as N.PLAT and D.PLAT (Table 6). The combination of SIZE, DEPTH and N.PLAT produced the highest correlation (Table 6). While these 3 variables appeared repeatedly in the 5 best subsets selected in the procedure, S.TEMP, B.TEMP and D.LAND were

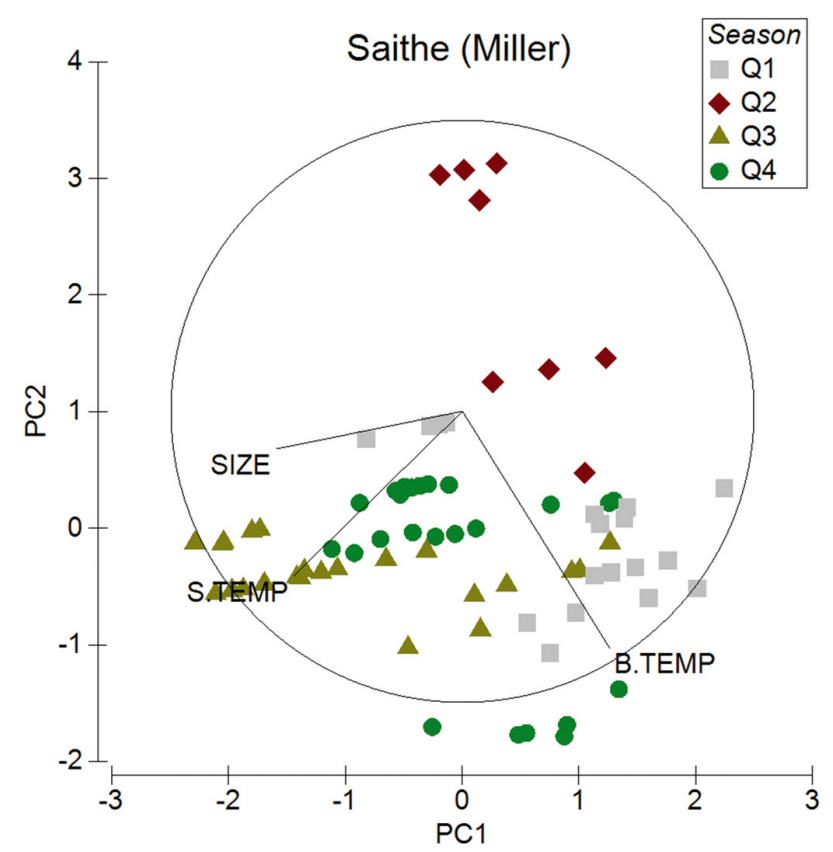

Fig. 5. Principal component (PC) analysis of 3 biotic and abiotic variables for saithe stomach data at the Miller platform (seasons Quarter [Q] 1 to Q4, see Table 1). Coding of environmental variables as in Table 5 

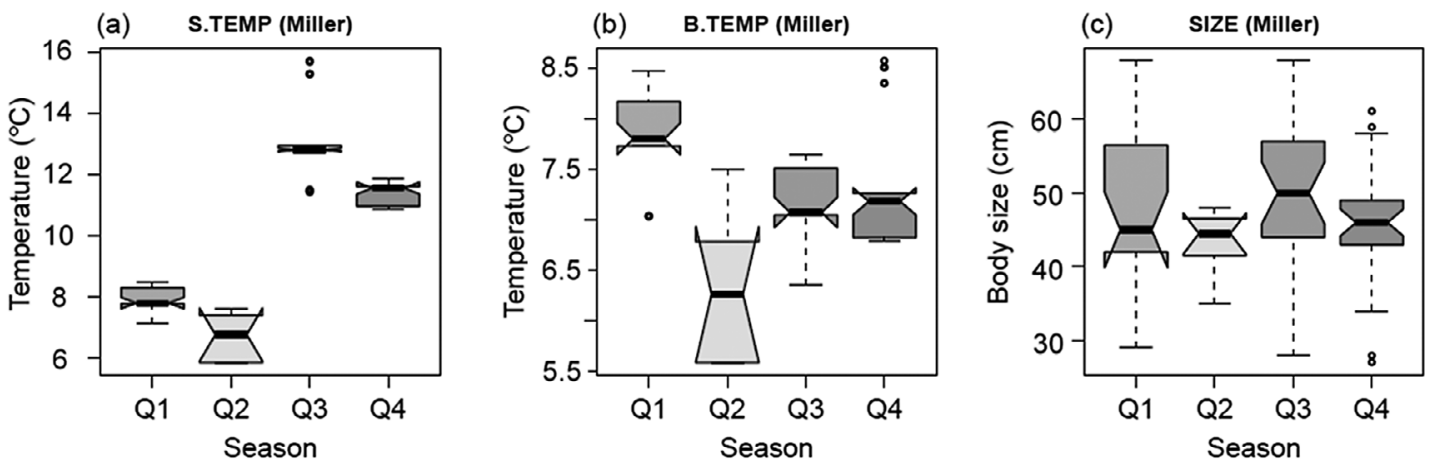

Fig. 6. Box plots showing between-season comparisons of saithe stomach data obtained at the Miller platform for (a) sea surface temperature (S.TEMP), (b) bottom temperature (B.TEMP) and (c) size (SIZE). Darker gray indicates a higher proportion of sample size per season. Q: Quarter. Mid-line: median; notch: approximate $95 \%$ CI for the median; box limits: top, bottom are 3rd, 1st quartiles, respectively; whiskers: max-min values; circles: outliers

Table 7. Summary trawl haul data of the International Bottom Trawl Survey on the FRV 'Scotia' where saithe was caught (cruise 0912S). Haul code in parentheses indicates the number of stomachs filled $\left(\mathrm{N}_{\mathrm{SF}}\right)$ was zero and hence could not be included in the analysis; S.TEMP: surface temperature $\left({ }^{\circ} \mathrm{C}\right)$; B.TEMP: bottom temperature $\left({ }^{\circ} \mathrm{C}\right)$; D.PLAT: distance to the nearest offshore oil and gas platform $(\mathrm{km})$; other codes as in Table $1_{i}-$ : not included

\begin{tabular}{|c|c|c|c|c|c|c|c|c|c|c|c|}
\hline \multirow{2}{*}{$\begin{array}{l}\text { Haul } \\
\text { code }\end{array}$} & \multirow{2}{*}{$\begin{array}{c}\text { Date } \\
\text { (dd.mm.yy) }\end{array}$} & \multicolumn{2}{|c|}{ Position } & \multirow{2}{*}{$\begin{array}{l}\text { ICES } \\
\text { rectangle }\end{array}$} & \multirow{2}{*}{$\begin{array}{l}\text { Depth } \\
\text { (m) }\end{array}$} & \multirow{2}{*}{$\begin{array}{l}\text { S.TEMP } \\
\left({ }^{\circ} \mathrm{C}\right)\end{array}$} & \multirow{2}{*}{$\begin{array}{l}\text { B.TEMP } \\
\left({ }^{\circ} \mathrm{C}\right)\end{array}$} & \multirow{2}{*}{$\begin{array}{l}\text { D.PLAT } \\
(\mathrm{km})\end{array}$} & \multirow[b]{2}{*}{$\mathrm{N}$} & \multicolumn{2}{|c|}{ _ Saithe } \\
\hline & & Latitude & Longitude & & & & & & & $\mathrm{N}_{\mathrm{SF}}$ & $\mathrm{L}_{\mathrm{T}} \pm \mathrm{SD}$ \\
\hline (S321) & 23.07 .12 & $55.937^{\circ} \mathrm{N}$ & $1.134^{\circ} \mathrm{W}$ & $40 \mathrm{E} 8$ & - & - & - & - & 2 & 0 & $29.5 \pm 0.7$ \\
\hline S352 & 30.07 .12 & $56.957^{\circ} \mathrm{N}$ & $1.590^{\circ} \mathrm{E}$ & $42 \mathrm{~F} 1$ & 100 & 14.5 & 7.5 & 16.1 & 1 & 1 & 48 \\
\hline (S360) & 02.08 .12 & $57.816^{\circ} \mathrm{N}$ & $2.589^{\circ} \mathrm{W}$ & $44 \mathrm{E} 7$ & - & - & - & - & 1 & 0 & 49 \\
\hline S368 & 04.08 .12 & $59.263^{\circ} \mathrm{N}$ & $3.482^{\circ} \mathrm{W}$ & $47 \mathrm{E} 6$ & 102 & 11.8 & 10.8 & 124.6 & 1 & 1 & 49 \\
\hline (S369) & 04.08 .12 & $59.551^{\circ} \mathrm{N}$ & $3.836^{\circ} \mathrm{W}$ & 48E6 & - & - & - & - & 1 & 0 & 41 \\
\hline S370 & 04.08 .12 & $59.629^{\circ} \mathrm{N}$ & $2.724^{\circ} \mathrm{W}$ & $48 \mathrm{E} 7$ & 75 & 11.1 & 11.1 & 119.6 & 7 & 7 & $38.1 \pm 3.4$ \\
\hline S372 & 05.08 .12 & $59.259^{\circ} \mathrm{N}$ & $1.502^{\circ} \mathrm{W}$ & $47 \mathrm{E} 8$ & 100 & 12.2 & 9.9 & 84.4 & 10 & 10 & $40.1 \pm 1.1$ \\
\hline (S373) & 05.08 .12 & $59.913^{\circ} \mathrm{N}$ & $1.714^{\circ} \mathrm{W}$ & 48E8 & - & - & - & - & 2 & 0 & $42.5 \pm 0.7$ \\
\hline (S374) & 05.08 .12 & $60.173^{\circ} \mathrm{N}$ & $1.609^{\circ} \mathrm{W}$ & 49E8 & - & - & - & - & 2 & 0 & $11.5 \pm 0.7$ \\
\hline S375 & 05.08 .12 & $60.223^{\circ} \mathrm{N}$ & $2.268^{\circ} \mathrm{W}$ & $49 \mathrm{E} 7$ & 126 & 12.4 & 9.8 & 54.6 & 10 & 6 & $40.7 \pm 3.7$ \\
\hline S377 & 06.08 .12 & $60.047^{\circ} \mathrm{N}$ & $3.293^{\circ} \mathrm{W}$ & 49E6 & 180 & 12.7 & 9.5 & 83.1 & 10 & 6 & $82.3 \pm 11.0$ \\
\hline S378 & 06.08 .12 & $60.575^{\circ} \mathrm{N}$ & $2.265^{\circ} \mathrm{W}$ & $50 \mathrm{E} 7$ & 156 & 12.7 & 9.6 & 20.0 & 5 & 3 & $45.0 \pm 4.6$ \\
\hline S379 & 06.08 .12 & $60.696^{\circ} \mathrm{N}$ & $1.703^{\circ} \mathrm{W}$ & 50E8 & 118 & 11.5 & 9.7 & 45.7 & 4 & 4 & $45.5 \pm 4.9$ \\
\hline S380 & 06.08 .12 & $61.018^{\circ} \mathrm{N}$ & $1.265^{\circ} \mathrm{W}$ & 51E8 & 132 & 12.8 & 9.6 & 78.2 & 10 & 10 & $41.1 \pm 1.9$ \\
\hline S381 & 06.08 .12 & $61.136^{\circ} \mathrm{N}$ & $0.670^{\circ} \mathrm{W}$ & 51E9 & 140 & 12.5 & 9.5 & 86.6 & 10 & 9 & $51.1 \pm 11.1$ \\
\hline S382 & 07.08 .12 & $60.125^{\circ} \mathrm{N}$ & $0.308^{\circ} \mathrm{W}$ & 49E9 & 140 & 13.9 & 8.8 & 115.0 & 10 & 10 & $72.0 \pm 6.6$ \\
\hline S383 & 07.08 .12 & $60.882^{\circ} \mathrm{N}$ & $0.013^{\circ} \mathrm{W}$ & 50E9 & 160 & 13.1 & 8.9 & 52.0 & 10 & 10 & $52.7 \pm 4.7$ \\
\hline S384 & 07.08 .12 & $60.626^{\circ} \mathrm{N}$ & $0.810^{\circ} \mathrm{E}$ & $50 \mathrm{~F} 0$ & 150 & 13.9 & 8.0 & 37.2 & 10 & 7 & $43.5 \pm 2.9$ \\
\hline S385 & 07.08 .12 & $60.716^{\circ} \mathrm{N}$ & $1.203^{\circ} \mathrm{E}$ & $50 \mathrm{~F} 1$ & 145 & 13.7 & 8.3 & 16.8 & 10 & 10 & $43.4 \pm 3.3$ \\
\hline S386 & 07.08 .12 & $60.548^{\circ} \mathrm{N}$ & $2.069^{\circ} \mathrm{E}$ & $50 F 2$ & 125 & 14.1 & 8.0 & 24.5 & 10 & 9 & $49.7 \pm 9.2$ \\
\hline S387 & 08.08 .12 & $59.683^{\circ} \mathrm{N}$ & $3.176^{\circ} \mathrm{E}$ & $48 \mathrm{~F} 3$ & 146 & 14.5 & 8.5 & 52.5 & 10 & 6 & $47.8 \pm 6.8$ \\
\hline S388 & 08.08.12 & $59.737^{\circ} \mathrm{N}$ & $2.419^{\circ} \mathrm{E}$ & $48 \mathrm{~F} 2$ & 113 & 14.5 & 8.1 & 21.2 & 2 & 2 & $61.0 \pm 14.1$ \\
\hline S389 & 08.08.12 & $59.614^{\circ} \mathrm{N}$ & $1.787^{\circ} \mathrm{E}$ & $48 \mathrm{~F} 1$ & 122 & 14.6 & 8.1 & 15.3 & 3 & 3 & $44.7 \pm 4.2$ \\
\hline S390 & 08.08 .12 & $59.688^{\circ} \mathrm{N}$ & $0.664^{\circ} \mathrm{E}$ & $48 \mathrm{~F} 0$ & 125 & 14.5 & 7.8 & 48.3 & 7 & 6 & $45.3 \pm 5.4$ \\
\hline S391 & 08.08 .12 & $59.685^{\circ} \mathrm{N}$ & $0.249^{\circ} \mathrm{W}$ & 48E9 & 130 & 13.2 & 8.0 & 96.4 & 10 & 7 & $40.5 \pm 2.1$ \\
\hline S392 & 09.08.12 & $59.046^{\circ} \mathrm{N}$ & $0.834^{\circ} \mathrm{W}$ & 47E9 & 130 & 14.5 & 8.0 & 39.7 & 8 & 8 & $45.1 \pm 10.7$ \\
\hline (S393) & 09.08.12 & $58.741^{\circ} \mathrm{N}$ & $0.760^{\circ} \mathrm{W}$ & $46 \mathrm{E} 9$ & - & - & - & - & 1 & 0 & 74 \\
\hline S395 & 09.08.12 & $58.081^{\circ} \mathrm{N}$ & $1.254^{\circ} \mathrm{E}$ & $45 \mathrm{~F} 1$ & 144 & 14.8 & 7.7 & 7.5 & 3 & 2 & $74.7 \pm 3.1$ \\
\hline S396 & 09.08.12 & $57.841^{\circ} \mathrm{N}$ & $0.334^{\circ} \mathrm{E}$ & $44 \mathrm{~F} 0$ & 135 & 15.1 & 7.9 & 28.3 & 2 & 2 & $49.0 \pm 1.4$ \\
\hline S397 & 10.08 .12 & $58.484^{\circ} \mathrm{N}$ & $0.233^{\circ} \mathrm{E}$ & $45 \mathrm{~F} 0$ & 140 & 15.2 & 7.6 & 2.4 & 7 & 5 & $59.3 \pm 3.0$ \\
\hline S399 & 10.08 .12 & $58.747^{\circ} \mathrm{N}$ & $2.600^{\circ} \mathrm{E}$ & $46 \mathrm{~F} 2$ & 110 & 15.1 & 7.7 & 47.3 & 6 & 5 & $52.8 \pm 17.0$ \\
\hline S400 & 10.08 .12 & $58.917^{\circ} \mathrm{N}$ & $3.377^{\circ} \mathrm{E}$ & $46 F 3$ & 125 & 15.4 & 8.0 & 57.9 & 10 & 6 & $56.8 \pm 15.4$ \\
\hline
\end{tabular}


(a) IBTS

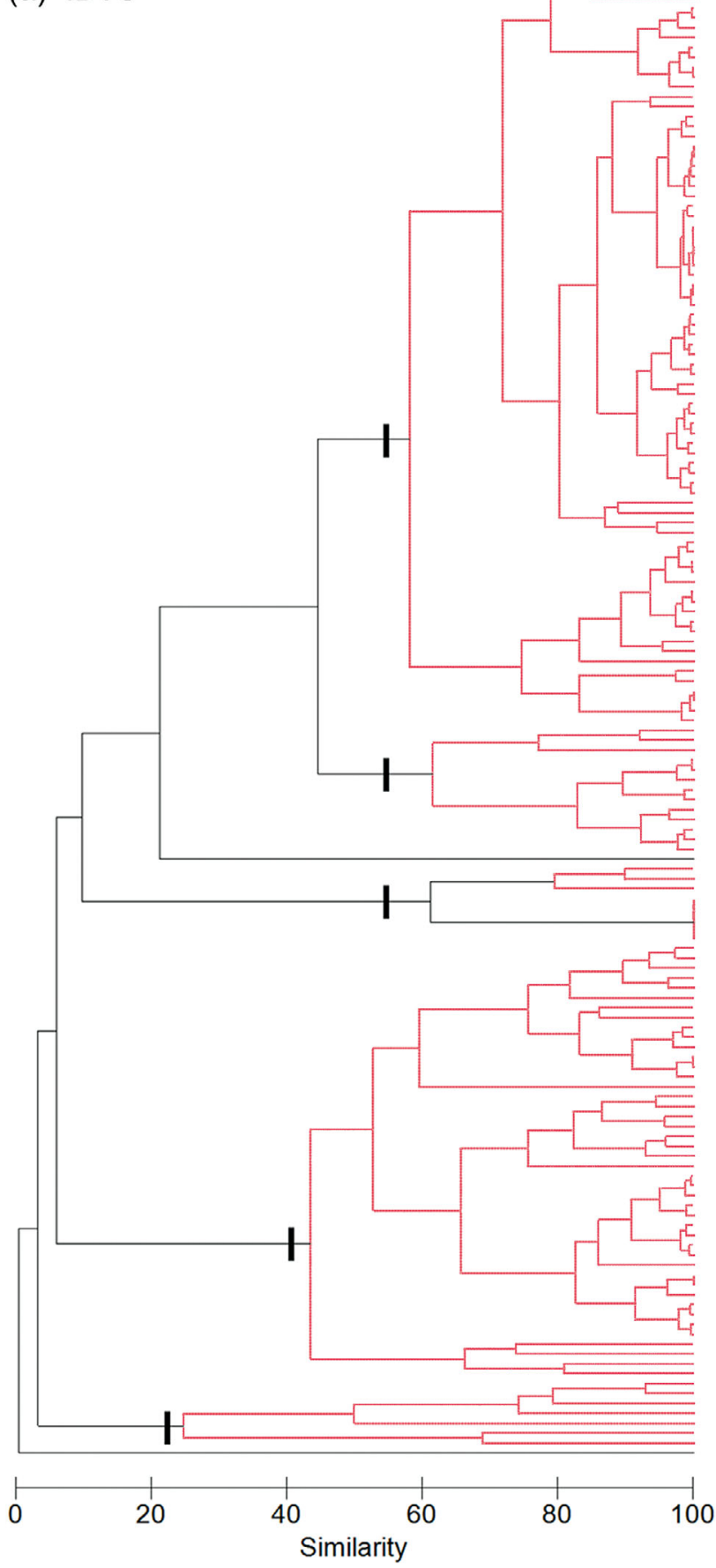

(b) Miller Q3

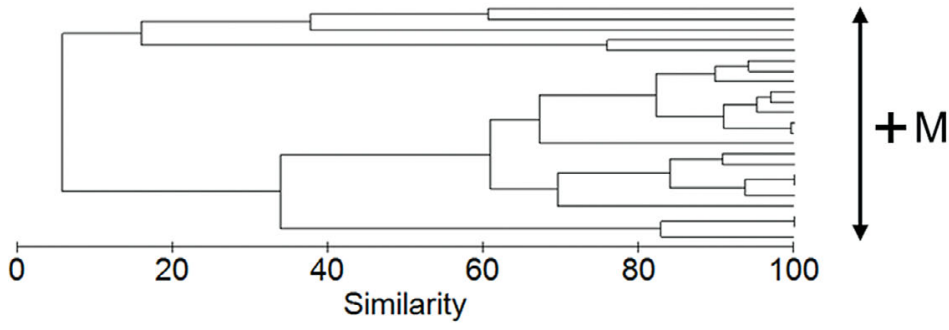

not selected in a single combination. The significant environmental variables identified in the BEST analysis (Table 6) were plotted against the respective cluster groups identified by the SIMPROF test (Fig. 8a-d). Saithe individuals in Clusters 2 and 5 were significantly larger in body sizes when compared with the rest of the clusters (Fig. 8a). Over $80 \%$ of saithe individuals belonged to either Cluster 1 or 4 (Fig. 7a), and these 2 clusters showed similar body size distributions (Fig. 8a). However, saithe individuals in Cluster 1 tended to be sampled at shallower depths than those in Cluster 4 (Fig. 8b). In addition, N.PLAT was relatively higher and D.PLAT was shorter in Cluster 4 than in Cluster 1 (Fig. 8c,d).

Finally, the spatial data taken from the IBTS survey (Fig. 7a) were combined with the Q3 data taken from the Miller platform (Fig. 7b), and the combined saithe stomach data (IBTS + Miller Q3) were re-grouped into mainly 5 new clusters, $1 \mathrm{M}$ to $5 \mathrm{M}$, based on cluster analysis 02 (Fig. 9). The original structure of Clusters 1 to 5 (Fig. 7a) essentially remained the same in the new groupings (Clusters $1 \mathrm{M}$ to $5 \mathrm{M}$ ), but a large proportion of saithe individuals $(78.3 \%)$ taken from the Q3 Miller platform was allocated to Cluster 4M (Fig. 9). The NMDS plot also illustrated the clear relations of the saithe stomach contents between the original clusters (Clusters 1 to 5) and the Miller Q3 data (Cluster M) (Fig. 10a). Clusters 2M, 3M and 5M still $\triangle 4$ remained low in sample sizes, comprising only $14(8.1 \%), 10(5.8 \%)$ and $7(4.1 \%)$ samples, respectively, whereas both Clusters $1 \mathrm{M}$ and $4 \mathrm{M}$ comprised $79(45.9 \%)$ and $62(36.0 \%)$ samples, respectively. The results of the SIMPER analysis for Clusters $1 \mathrm{M}$ to $5 \mathrm{M}$ were almost identical to those for the previous Clusters 1 to 5 (Fig. 4c,d, Tables 8 \& 9). However, the RELATE tests showed that more individual explanatory variables were significantly correlated with the resemblance matrix on the combined saithe stomach data, with SIZE still

Fig. 7. Multivariate analysis of saithe stomach data for the (a) International Bottom Trawl Survey (IBTS) and (b) Miller platform (Quarter [Q] 3), showing dendrogram based on square root transformation, BrayCurtis similarity and group average clustering. In (a), 5 main clusters of individual samples (black branches) were identified based on the SIMPROF test $(p<0.05)$. NA: not applicable 
Table 8. Analysis of stomach contents of saithe in relation to Clusters 1 to 5. Breakdown of average dissimilarities between cluster groups, with percentage contributions of prey items which accounted for most $(>90 \%$ ) of those values based on SIMPER analysis. Relative stomach contents are arcsine transformed data in weight (g). Abbreviated genus names as in Fig. 2; other abbreviations as in Table 4

\begin{tabular}{|c|c|c|c|c|c|}
\hline \multirow[t]{2}{*}{ Prey item } & \multicolumn{2}{|c|}{$\begin{array}{c}\text { Relative } \\
\text { stomach contents }\end{array}$} & \multirow{2}{*}{$\begin{array}{c}\text { Contrib. } \\
\qquad(\%)\end{array}$} & \multirow{2}{*}{$\begin{array}{c}\text { Cum. } \\
\text { contrib. } \\
(\%)\end{array}$} & \multirow{2}{*}{$\begin{array}{r}\text { Av. } \\
\text { diss } \\
(\%)\end{array}$} \\
\hline & Cluster 1 & Cluster 2 & & & \\
\hline T. esmarkii & 2.59 & 7.80 & 81.7 & 81.7 & \\
\hline \multirow[t]{2}{*}{ A. sphyraena } & 0.00 & 1.21 & 12.0 & 93.6 & \\
\hline & Cluster 1 & Cluster 3 & & & 89.1 \\
\hline \multirow[t]{2}{*}{ T. esmarkii } & 2.59 & 0.13 & 95.5 & 95.5 & \\
\hline & Cluster 1 & Cluster 4 & & & 93.1 \\
\hline T. esmarkii & 2.59 & 0.07 & 68.4 & 68.4 & \\
\hline \multirow[t]{2}{*}{ Euphausiacea } & 0.13 & 1.13 & 30.2 & 98.6 & \\
\hline & Cluster 1 & Cluster 5 & & & 95.9 \\
\hline S. scombrus & 0.00 & 10.28 & 55.4 & 55.4 & \\
\hline T. esmarkii & 2.59 & 3.49 & 18.8 & 74.2 & \\
\hline C. harengus & 0.00 & 2.25 & 8.3 & 82.5 & \\
\hline \multirow[t]{2}{*}{ G. argenteus } & 0.00 & 2.13 & 8.0 & 90.6 & \\
\hline & Cluster 2 & Cluster 3 & & & 97.0 \\
\hline T. esmarkii & 7.80 & 0.13 & 88.9 & 88.9 & \\
\hline \multirow[t]{2}{*}{ A. sphyraena } & 1.21 & 0.00 & 7.9 & 96.8 & \\
\hline & Cluster 2 & Cluster 4 & & & 98.5 \\
\hline T. esmarkii & 7.80 & 0.07 & 78.3 & 78.3 & \\
\hline Euphausiacea & 0.00 & 1.13 & 11.3 & 89.6 & \\
\hline \multirow[t]{2}{*}{ A. sphyraena } & 1.21 & 0.00 & 7.3 & 96.9 & \\
\hline & Cluster 2 & Cluster 5 & & & 89.1 \\
\hline S. scombrus & 0.00 & 10.28 & 44.2 & 44.2 & \\
\hline T. esmarkii & 7.80 & 3.49 & 28.9 & 73.0 & \\
\hline C. harengus & 0.00 & 2.25 & 7.3 & 80.3 & \\
\hline G. argenteus & 0.00 & 2.13 & 6.9 & 87.3 & \\
\hline \multirow[t]{2}{*}{ Ammodytidae } & 0.00 & 1.73 & 4.6 & 91.9 & \\
\hline & Cluster 3 & Cluster 4 & & & 95.5 \\
\hline Euphausiacea & 0.00 & 1.13 & 82.5 & 82.5 & \\
\hline \multirow[t]{2}{*}{ T. esmarkii } & 0.13 & 0.07 & 13.6 & 96.1 & \\
\hline & Cluster 3 & Cluster 5 & & & 99.8 \\
\hline S. scombrus & 0.00 & 10.28 & 62.3 & 62.3 & \\
\hline T. esmarkii & 0.13 & 3.49 & 11.2 & 73.4 & \\
\hline C. harengus & 0.00 & 2.25 & 8.8 & 82.2 & \\
\hline \multirow[t]{2}{*}{ G. argenteus } & 0.00 & 2.13 & 8.6 & 90.8 & \\
\hline & Cluster 4 & Cluster 5 & & & 99.9 \\
\hline S. scombrus & 0.00 & 10.28 & 58.1 & 58.1 & \\
\hline T. esmarkii & 0.07 & 3.49 & 10.5 & 68.6 & \\
\hline C. harengus & 0.00 & 2.25 & 8.4 & 77.0 & \\
\hline G. argenteus & 0.00 & 2.13 & 8.2 & 85.2 & \\
\hline Euphausiacea & 1.13 & 0.00 & 5.8 & 91.0 & \\
\hline
\end{tabular}

showing the highest correlation, followed by D.PLAT, DEPTH, N.PLAT and D.LAND (Table 5). Both S.TEMP and B.TEMP, however, were not significantly correlated with the stomach contents resemblance (Table 5). The BEST analysis also revealed that the 5 best subsets of environmental variables were combinations of SIZE, D.PLAT, DEPTH, N.PLAT and S.TEMP, and the combination of SIZE and D.PLAT produced the highest correlation (Table 6). While these 2 variables appeared in every combination of the 5 best subsets selected in the procedure, both D.LAND and B.TEMP were not selected in a single combination (Table 6). The PCA of the explanatory variables showed the clear influences of factors associated with environmental and biological conditions as well as those associated with the physical presence of offshore platforms along the first 2 PC axes, which explained $75.4 \%$ of the total variance (Fig. 10b). PC axis 1 (51.3\% of total variance) was mainly influenced by D.PLAT, N.PLAT and D.LAND, variables potentially linked with the sphere of influence exerted by the physical presence of the offshore platforms. PC axis $2(24.1 \%$ of total variance) was mainly dominated by gradients of SIZE, DEPTH and S.TEMP, reflecting the environmental and biological influences associated with selectivity of prey items and habitat preference (Fig. 5b).

The box plots for the significant environmental variables identified in the BEST analysis against the new Clusters $1 \mathrm{M}$ to $5 \mathrm{M}$ now showed that Clusters $1 \mathrm{M}$ and $4 \mathrm{M}$ did not essentially differ in terms of their body size distributions and sampling depths (Fig. 8e,f). However, the distance to the nearest platform was markedly shorter and the number of platforms per unit area was markedly higher in Cluster $4 \mathrm{M}$ than in any other cluster (Fig. 8g,h).

\section{DISCUSSION}

This study revealed general patterns in the feeding habits of the major fish species closely associated with an offshore oil platform in the North Sea. Commercially important gadoids such as saithe, haddock and cod were the most characteristic species regularly caught at the Miller platform, and the prey compositions in their diets were significantly different between species, indicating that offshore installations provide unique feeding grounds for a variety of fish species within a single location and thereby allow for interspecific prey resource partitioning among those species closely associated with the structure. 

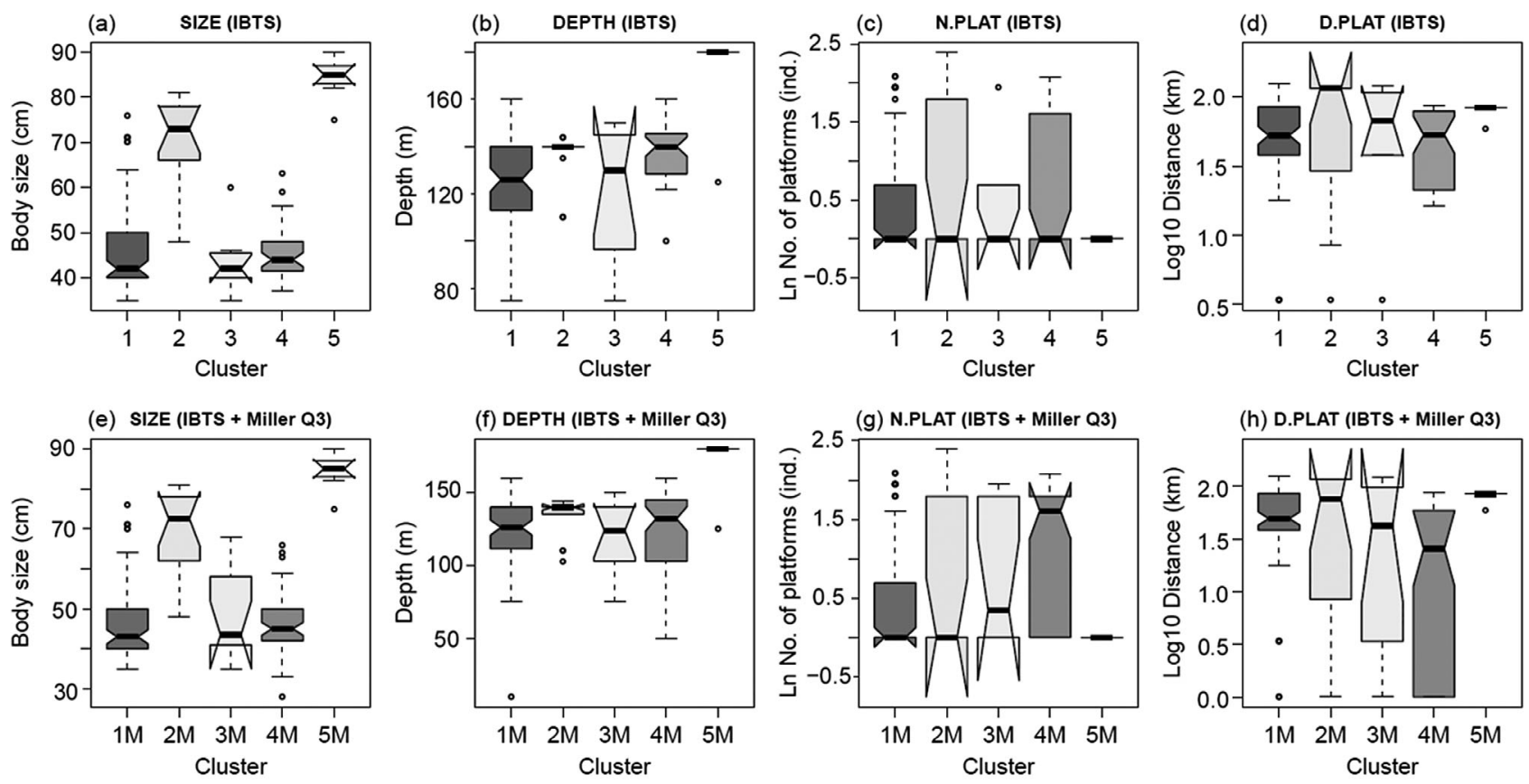

Fig. 8. Box plots showing between-cluster comparisons of saithe stomach data obtained in the International Bottom Trawl Survey (IBTS) for (a) SIZE, (b) DEPTH, (c) number of platforms (N.PLAT) and (d) distance to nearest platform (D.PLAT) and in the IBTS survey + Miller Quarter 3 (Q3) for (e) SIZE, (f) DEPTH, (g) N.PLAT and (h) D.PLAT. Darker gray indicates a higher proportion of sample size per cluster. For box-plot definitions, see Fig. 6

The composition of prey items found in the fish stomachs at the Miller platform broadly corresponded with the results of previous diet studies conducted at different habitat types (e.g. Du Buit 1991, Høines \& Bergstad 1999, Jaworski \& Ragnarsson 2006). For example, both haddock and cod are demersal fish, and haddock tends to be more associated with soft-bottom habitats, feeding predominantly on small and slowmoving benthic invertebrates such as echinoids, ophiuroids and polychaetes (Schückel et al. 2010), whereas cod is more associated with harder substrates, becoming increasingly piscivorous (Mattson 1990, Wieland et al. 2009). In contrast, saithe is more benthopelagic, and the diet of this species tends to be strongly oriented towards pelagic prey, e.g. zooplankton, small pelagic fish and cephalopods, often with $>50 \%$ of the diet comprised of euphausiids (e.g. Du Buit 1991, Carruthers et al. 2005). Tusk is generally associated with deep-sea cold-water coral reef habitats and feeds predominantly on epibenthic decapods, e.g. Munida spp. and brachyuran crabs (Husebø et al. 2002). This was in good agreement with the observation made in this study in which tusk was found to feed on similar epibenthic crustaceans such as brachyuran crabs and hermit crabs (Anomura).

One of the main findings in this study was that these varieties of invertebrate prey items, which are normally associated with different habitat types, were found in the diets of fish samples taken within a single location at the Miller platform. For example, recent research literature suggests that ophiuroids, which were found to be dominant components in the diet of haddock, are commonly found in high abundance on platforms at all depths, and other prey items such as bryozoans, hydrozoans, bivalves, actiniarians and cirripedes are the typical fouling organisms commonly found on the surface of the jacket legs of the platforms (Whomersley \& Picken 2003, Guerin 2009). The formation of these fouling organisms on platforms in turn provides structurally heterogeneous microhabitats for polychaete worms and crustaceans such as caridean shrimps and peracarids such as isopods and amphipods as well as epibenthic organisms such as anomuran and brachyuran crabs, which altogether characterised the compositions of the fish stomach contents at the Miller platform. The significant interspecific patterns of dietary differences observed in this study therefore strongly suggest that offshore oil and gas installations provide unique feeding grounds for a range of fish species and thereby function as artificial reefs which possess a range of habitat types throughout the entire water column as well as an array of associated prey items in high concentrations, effectively facilitating a small- 


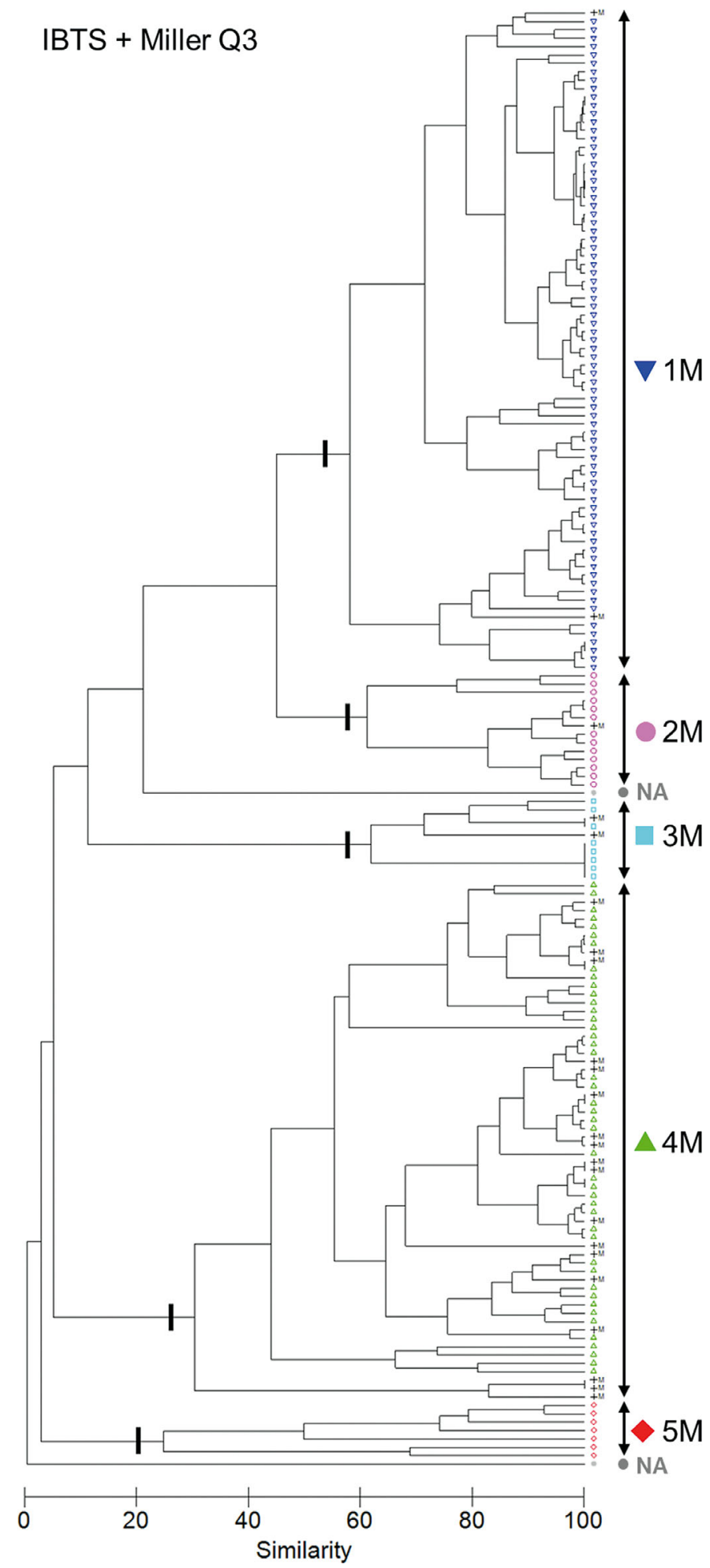

Fig. 9. Multivariate analysis of the combined saithe stomach data for the International Bottom Trawl Survey (IBTS) and Miller platform (Quarter 3 [Q3]), showing dendrogram based on square root transformation, Bray-Curtis similarity and group average clustering. The symbols in the dendrogram denote the previous groupings as in Fig. 7a (Clusters 1 to 5) and Fig. $7 \mathrm{~b}$ (Cluster M); NA: not applicable scale spatial segregation and resource partitioning among those fish species closely associated with the platform.

Saithe was the most characteristic species observed at the Miller platform throughout the year, and when the temporal patterns of the saithe diet were further examined in relation to biotic and abiotic factors, the observed variability in the diet was significantly explained by changes in surface and bottom temperature, which also mirrored changes in the proportion of euphausiids in the saithe diet. The observed relationships between saithe stomach contents, euphausiids and the seawater temperature seem to reflect the seasonal cycle of the occurrence/availability of euphausiids in the North Sea. Euphausiids reproduce in the late winter-early spring, after which most of the mature adults die (Lindley 1982). The high production rates of euphausiids then follow in the late spring as a result of the emergence of large numbers of young in the population (Greenstreet et al. 1997). Interestingly, euphausiids did not occur in the saithe stomach contents consistently in the spring months (Q2), where the catches/abundances of saithe were also at the lowest in comparison with other seasons throughout the study period at the Miller platform. Similar patterns of temporal variation in local saithe abundance and their resource use were reported in young saithe from the fjord systems off the coast of Norway. Observations have shown that euphausiids disappeared from the fjord systems in February and March, followed by the great migration of young saithe away from the coast during spring (Nedreaas 1987), suggesting the potential links between the seasonal availability of euphausiids and the subsequent distributional response of saithe individuals. Similarly, Høines \& Bergstad (1999) investigated temporal variation in the diets of gadoid fishes on herring spawning grounds off southwestern Norway and showed that the diet of saithe abruptly shifted to consume predominantly herring eggs in March and April, when euphausiid abundances were low. Further, Carruthers et al. (2005) investigated longterm changes in the feeding patterns and physical conditions of saithe individuals in the northwestern Atlantic and found that the abundance of euphausiids was a significant determinant of the nutritional state of saithe populations. Euphausiids could therefore be the most important prey type sought after by saithe populations, and spatio-temporal variation in the abundance and movements of saithe may therefore be regulated by variation in the availability of euphausiids over time and space. 

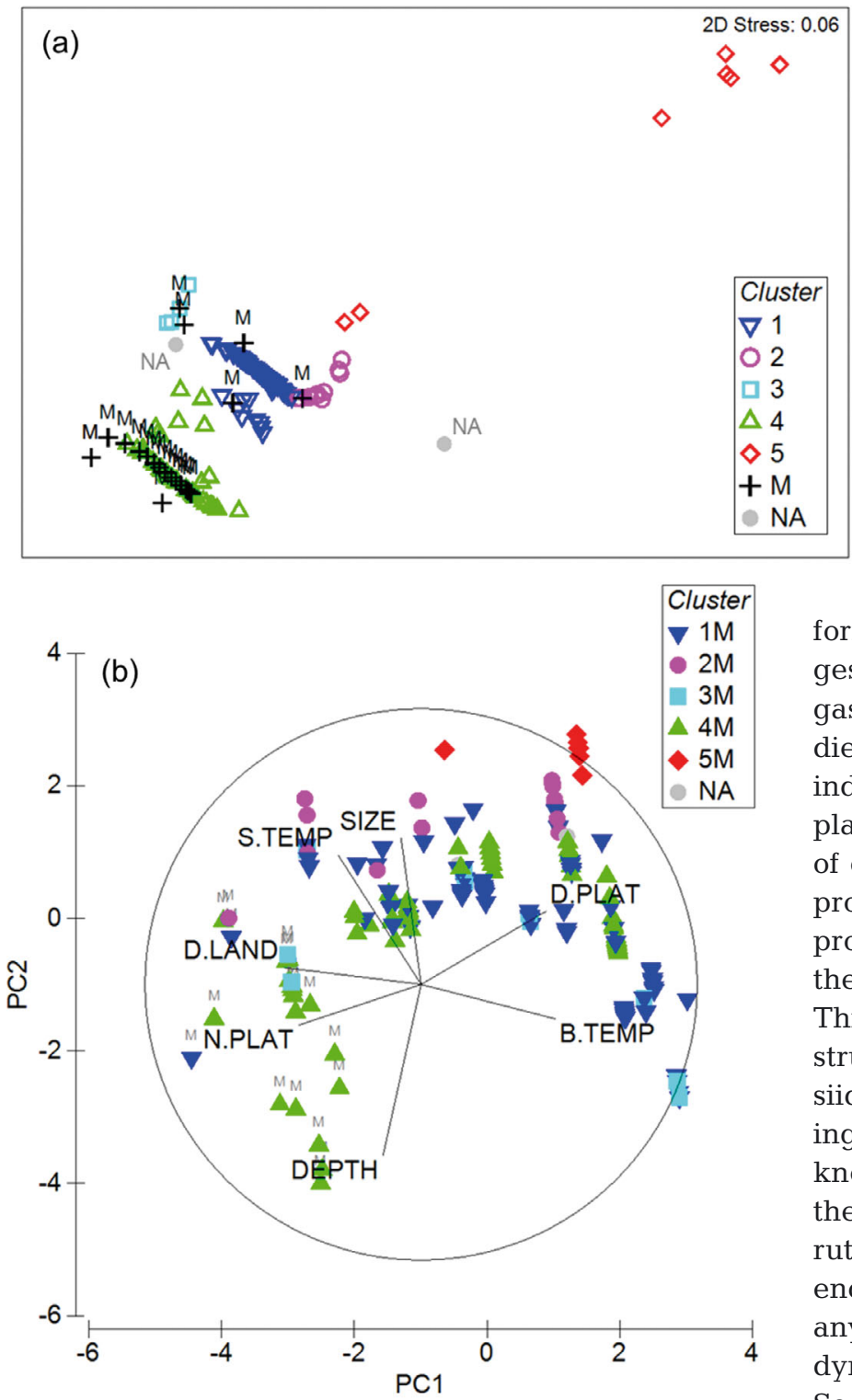

Fig. 10. (a) Result of the multivariate analysis of saithe stomach contents obtained across the North Sea (IBTS + Miller Q3) showing non-metric multidimensional scaling ordination (symbols as in Fig. 7a,b). (b) Principal component (PC) analysis of 7 biotic and abiotic variables for saithe stomach data across the North Sea (IBTS + Miller Q3). Coding of environmental variables as in Table 5, symbols as in Fig. 9. $\mathrm{M}$ denotes samples from the Q3 Miller platform. IBTS: International Bottom Trawl Survey; Q: Quarter (season; see Table 1)

Another important consideration is that when the spatial patterns of the saithe diet were examined in relation to biotic and abiotic factors, the observed variability in the diet was significantly explained by body size and proximity to the individual oil and gas platforms across the sampling stations in the North Sea. This trend was even stronger when the Q3 data at the Miller platform were combined with the IBTS spatial data. The multivariate analysis on the combined data thus revealed that, among 172 individual samples, 5 significant dietary groupings were distinguished (i.e. Clusters $1 \mathrm{M}$ to $5 \mathrm{M}$ ). Saithe individuals in Cluster 1M (45.9\%) were mainly sampled from the FRV 'Scotia' or at locations relatively farther away from offshore platforms. Saithe individuals in Cluster 4M (36.0\%) were sampled either at the Miller platform or from the FRV 'Scotia' relatively closer to other platforms across the North Sea. The multivariate analysis also showed that the variation in saithe diet was significantly influenced by the number of offshore platforms per unit area where they were sampled, suggesting that the physical presence of offshore oil and gas platforms can have a significant influence on the diet and feeding habits of saithe populations. Saithe individuals in Cluster 4M, sampled closer to offshore platforms or in areas that had higher concentrations of offshore structures, showed a significantly higher proportion of euphausiids but a significantly lower proportion of Norway pout Trisopterus esmarkii in their diet when compared with those in Cluster $1 \mathrm{M}$. This suggests that the physical presence of offshore structures may in fact attract populations of euphausiids, which in turn affect the distribution and feeding habits of saithe populations. Euphausiids are known to play a vital role in shaping the structure of the marine food web (e.g. Christensen 1995, Carruthers et al. 2005) and therefore are likely to influence not only the feeding ecology of saithe but also any other marine life that are interconnected to the dynamics of such trophic interactions. In the North Sea, for example, both $T$. esmarkii and mackerel Scomber scombrus serve as an important food source for many of the commercially important predatory fish, such as cod and saithe. However, T. esmarkii and mackerel are also known to be important predators on euphausiids (Christensen 1995). Interestingly, large aggregations of both $T$. esmarkii and mackerel have also been frequently observed near the North Sea oil platforms (e.g. Aabel et al. 1997, Soldal et al. 2002, Guerin 2009), and their occurrences may therefore be explained by the potential association between the local availability of euphausiids and the physical presence of the offshore platforms. In addition, the significant reduction of the proportion of $T$. esmarkii in the saithe stomach contents in Cluster $4 \mathrm{M}$ may be attributable to the enhanced availability of euphausiids around the offshore structures, which 
Table 9. Analysis of stomach contents of saithe in relation to Clusters $1 \mathrm{M}$ to 5M. Breakdown of average dissimilarities between cluster groups, with percentage contributions of prey items which accounted for most $(>90 \%)$ of those values based on SIMPER analysis. Relative stomach contents are square root transformed data in weight (g). Abbreviated genus names as in Fig. 2: other abbreviations as in Table 4

\begin{tabular}{|c|c|c|c|c|c|}
\hline Prey item & \multicolumn{2}{|c|}{$\begin{array}{c}\text { Relative } \\
\text { stomach contents }\end{array}$} & \multirow{2}{*}{$\begin{array}{c}\text { Contrib. } \\
\qquad(\%)\end{array}$} & \multirow{2}{*}{$\begin{array}{c}\text { Cum. } \\
\text { contrib. } \\
(\%)\end{array}$} & \multirow{2}{*}{$\begin{array}{r}\begin{array}{r}\text { Av. } \\
\text { diss. } \\
(\%)\end{array} \\
\mathbf{5 5 . 0}\end{array}$} \\
\hline & Cluster 1M & Cluster 2M & & & \\
\hline T. esmarkii & 2.56 & 7.69 & 82.5 & 82.5 & \\
\hline A. sphyraena & 0.00 & 1.12 & 11.2 & 93.7 & \\
\hline T. esmarkii & $\begin{array}{c}\text { Cluster } 1 \mathbf{M} \\
2.56\end{array}$ & $\begin{array}{c}\text { Cluster } \mathbf{3 M} \\
0.15\end{array}$ & 95.1 & 95.1 & 87.5 \\
\hline $\begin{array}{l}\text { T. esmarkii } \\
\text { Euphausiacea }\end{array}$ & $\begin{array}{c}\text { Cluster 1M } \\
2.56 \\
0.14\end{array}$ & $\begin{array}{c}\text { Cluster } 4 \mathbf{M} \\
0.05 \\
1.03\end{array}$ & $\begin{array}{l}70.2 \\
28.2\end{array}$ & $\begin{array}{l}70.2 \\
98.5\end{array}$ & 94.0 \\
\hline $\begin{array}{l}\text { S. scombrus } \\
\text { T. esmarkii } \\
\text { C. harengus } \\
\text { G. argenteus }\end{array}$ & $\begin{array}{c}\text { Cluster 1M } \\
0.00 \\
2.56 \\
0.00 \\
0.00\end{array}$ & $\begin{array}{c}\text { Cluster } \mathbf{5 M} \\
10.28 \\
3.49 \\
2.25 \\
2.13\end{array}$ & $\begin{array}{c}55.5 \\
18.7 \\
8.3 \\
8.0\end{array}$ & $\begin{array}{l}55.5 \\
74.2 \\
82.5 \\
90.5\end{array}$ & 96.0 \\
\hline $\begin{array}{l}\text { T. esmarkii } \\
\text { A. sphyraena }\end{array}$ & $\begin{array}{c}\text { Cluster 2M } \\
7.69 \\
1.12\end{array}$ & $\begin{array}{c}\text { Cluster } 3 \mathbf{M} \\
0.15 \\
0.00\end{array}$ & $\begin{array}{c}89.6 \\
7.4\end{array}$ & $\begin{array}{l}89.6 \\
97.0\end{array}$ & 96.4 \\
\hline $\begin{array}{l}\text { T. esmarkii } \\
\text { Euphausiacea }\end{array}$ & $\begin{array}{c}\text { Cluster 2M } \\
7.69 \\
0.00\end{array}$ & $\begin{array}{c}\text { Cluster } 4 \mathbf{M} \\
0.05 \\
1.03\end{array}$ & $\begin{array}{l}79.7 \\
10.6\end{array}$ & $\begin{array}{l}79.7 \\
90.3\end{array}$ & 99.0 \\
\hline $\begin{array}{l}\text { S. scombrus } \\
\text { T. esmarkii } \\
\text { C. harengus } \\
\text { G. argenteus } \\
\text { Ammodytidae }\end{array}$ & $\begin{array}{c}\text { Cluster 2M } \\
0.00 \\
7.69 \\
0.00 \\
0.00 \\
0.00\end{array}$ & $\begin{array}{c}\text { Cluster 5M } \\
10.28 \\
3.49 \\
2.25 \\
2.13 \\
1.73\end{array}$ & $\begin{array}{c}44.5 \\
28.8 \\
7.3 \\
7.0 \\
4.7\end{array}$ & $\begin{array}{l}44.5 \\
73.3 \\
80.6 \\
87.6 \\
92.2\end{array}$ & 89.2 \\
\hline $\begin{array}{l}\text { Euphausiacea } \\
\text { T. esmarkii }\end{array}$ & $\begin{array}{c}\text { Cluster 3M } \\
0.00 \\
0.15\end{array}$ & $\begin{array}{c}\text { Cluster } 4 \mathbf{M} \\
1.03 \\
0.05\end{array}$ & $\begin{array}{l}79.9 \\
16.5\end{array}$ & $\begin{array}{l}79.9 \\
96.4\end{array}$ & 96.7 \\
\hline $\begin{array}{l}\text { S. scombrus } \\
\text { T. esmarkii } \\
\text { C. harengus } \\
\text { G. argenteus }\end{array}$ & $\begin{array}{c}\text { Cluster 3M } \\
0.00 \\
0.15 \\
0.00 \\
0.00\end{array}$ & $\begin{array}{c}\text { Cluster } \mathbf{5 M} \\
10.28 \\
3.49 \\
2.25 \\
2.13\end{array}$ & $\begin{array}{c}62.2 \\
11.2 \\
8.8 \\
8.6\end{array}$ & $\begin{array}{l}62.2 \\
73.5 \\
82.2 \\
90.8\end{array}$ & 99.7 \\
\hline & Cluster 4M & Cluster $5 \mathrm{M}$ & & & 99.9 \\
\hline $\begin{array}{l}\text { S. scombrus } \\
\text { T. esmarkii }\end{array}$ & $\begin{array}{l}0.00 \\
0.05\end{array}$ & $\begin{array}{c}10.28 \\
3.49\end{array}$ & $\begin{array}{l}58.5 \\
10.5\end{array}$ & $\begin{array}{l}58.5 \\
69.0\end{array}$ & \\
\hline C. harengus & 0.00 & 2.25 & 8.5 & 77.5 & \\
\hline G. argenteus & 0.00 & 2.13 & 8.2 & 85.7 & \\
\hline Euphausiacea & 1.03 & 0.00 & 5.3 & 91.0 & \\
\hline
\end{tabular}

may relax the predation pressure of saithe on $T$. esmarkii and thereby permit these predator-prey species to coexist around the offshore installations. Any increase in local fish diversity and/or abundances around offshore platforms may in turn attract even higher trophic levels nearby, since there has been some initial evidence that marine mammals such as harbour porpoises and gray seals feed preferentially near North Sea offshore infrastructures (Todd et al. 2009, Russell et al. 2014).

The potential links between the distribution of euphausiids and the North Sea food web in association with the physical presence of offshore structures, however, have yet to be critically evaluated. For example, Fig. 2f indicates sampling locations where saithe stomach contents were associated with euphausiids, and it is noticeable that, apart from S352, the distribution of these stations is generally constrained in the northern North Sea along the edge of the Norwegian Deep (Fig. 1), where higher concentrations of saithe individuals would also normally be associated (Fujii 2015). If euphausiids naturally occur in high abundance around this geological feature (i.e. the edge of the Norwegian Deep), the physical presence of the offshore structures may well have little influence on the predator-prey relationship between saithe and euphausiids. At a local scale, however, seafloor features, such as coral reefs, slopes and sea mounts, could increase the density and abundance of zooplankton (i.e. euphausiids) in the immediate surroundings through hydrographically mediated factors (Dower \& Mackas 1996, Genin 2004). Further, all manned platforms are normally illuminated during the night, and the network of the artificial light field provided by these platforms may generate sufficient illumination to affect the local distribution of phototaxic prey invertebrates including zooplankton (Keenan et al. 2007, McConnell et al. 2010). It would therefore be of great interest to explore in future research how the spatio-temporal variation in the distribution of euphausiids is related to the physical presence of offshore platforms and how other environmental processes in turn affect the strength and dynamics of predator-prey dependencies in relation to any changes in the number and/or distribution of offshore man-made structures.

Overall, this study demonstrated that offshore oil and gas installations provide a unique feeding ground for a variety of commercially important fish species in the North Sea. However, many offshore petroleum fields are currently approaching the end 
of their commercial lives, and the focus is now shifting towards the fate of obsolete oil facilities since alternative disposal options may make significant differences in both environmental effects and economic consequences. Given the potential links between the physical presence of the offshore manmade structures and spatio-temporal variation in the utilisation patterns of prey resources by fish populations as demonstrated in this study, there is a need to improve our understanding for further insights into the influence of the decommissioning of offshore oil and gas installations on the structure and dynamics of the marine food web, which will in turn affect the functioning of marine ecosystem in the North Sea. Focus should therefore be given to integrating systematic sampling at spatio-temporal scales relevant to the ecosystem-based approach, which will allow for a more comprehensive analysis of the patterns of trophic interactions and the dynamics of the marine food web in relation to changes in the number and/or distribution of offshore man-made structures. Such an approach will be of paramount importance to better understand the true ecological consequences of different decommissioning alternatives and to facilitate effective spatial management of marine ecosystems in the North Sea as well as other offshore areas across the world.

Acknowledgements. The author thanks OSPAR for providing data for offshore oil and gas structures in the North Sea and Imants G. Priede, Alan Jamieson, Jim Mair, Inigo Martinez, Michelle Horsfield, Anne Walls and all the crew members of BP's Miller platform and the FRV 'Scotia', cruise 0912S, in particular Chief Scientist Finlay Burns, for invaluable advice and support in conducting this fish biology project. This work was coordinated by Oceanlab, University of Aberdeen, and was supported by the BP Fellowship in Applied Fisheries Programme.

\section{LITERATURE CITED}

Aabel JP, Cripps SJ, Jensen AC, Picken G (1997) Creating artificial reefs from decommissioned platforms in the North Sea: a review of knowledge and proposed programme of research. Offshore Decommissioning Communications Project, London

> Carruthers EH, Neilson JD, Waters C, Perley P (2005) Longterm changes in the feeding of Pollachius virens on the Scotian Shelf: responses to a dynamic ecosystem. J Fish Biol 66:327-347

Christensen V (1995) A model of trophic interactions in the North Sea in 1981, the year of the stomach. Dana 11:1-28

> Claisse JT, Pondella DJ, Love M, Zahn LA, Williams CM, Williams JP, Bull AS (2014) Oil platforms off California are among the most productive marine fish habitats globally. Proc Natl Acad Sci USA 111:15462-15467

Clarke KR, Warwick RM (2001) Change in marine commu- nities: an approach to statistical analysis and interpretation. Primer-E, Plymouth

Dempster T, Sanchez-Jerez P, Fernandez-Jover D, BayleSempere J, Nilsen R, Bjorn PA, Uglem I (2011) Proxy measures of fitness suggest coastal fish farms can act as population sources and not ecological traps for wild gadoid fish. PLoS ONE 6:e15646

> Dower JF, Mackas DL (1996) 'Seamount' effects in zooplankton community near Cobb Seamount. Deep-Sea Res 43:837-858

Du Buit MH (1991) Food and feeding of saithe (Pollachius virens L.) off Scotland. Fish Res 12:307-323

> Ducrotoy JP, Elliott M, De Jonge VN (2000) The North Sea. Mar Pollut Bull 41:5-23

> Fabi G, Grati F, Puletti M, Scarcella G (2004) Effects on fish community induced by installation of two gas platforms in the Adriatic Sea. Mar Ecol Prog Ser 273:187-197

> Friedlander AM, Ballesteros E, Fay M, Sala E (2014) Marine communities on oil platforms in Gabon, West Africa: high biodiversity oases in a low biodiversity environment. PLoS ONE 9:e103709

Fujii T (2015) Temporal variation in environmental conditions and the structure of fish assemblages around an offshore oil platform in the North Sea. Mar Environ Res 108: 69-82

Genin A (2004) Bio-physical coupling in the formation of zooplankton and fish aggregations over abrupt topographies. J Mar Syst 50:3-20

Greenstreet SPR, Bryant AD, Broekhuizen N, Hall SJ, Heath MR (1997) Seasonal variation in the consumption of food by fish in the North Sea and implications for food web dynamics. ICES J Mar Sci 54:243-266

Guerin AJ (2009) Marine communities of North Sea offshore platforms, and the use of stable isotopes to explore artificial reef food webs. $\mathrm{PhD}$ thesis, University of Southampton

Halpern BS, Walbridge S, Selkoe KA, Kappel CV and others (2008) A global map of human impact on marine ecosystems. Science 319:948-952

Hoegh-Guldberg O, Bruno JF (2010) The impact of climate change on the world's marine ecosystems. Science 328: 1523-1528

> Høines ÅS, Bergstad OA (1999) Resource sharing among cod, haddock, saithe and pollack on a herring spawning ground. J Fish Biol 55:1233-1257

> Husebø Å, Nøttestad L, Fosså JH, Furevik DM, Jørgensen SB (2002) Distribution and abundance of fish in deep-sea coral habitats. Hydrobiologia 471:91-99

ICES (International Council for the Exploration of the Sea) (2010) Addendum 1: IBTS manual-revision VIII. Manual for the International Bottom Trawl Surveys. The International Bottom Trawl Survey Working Group. ICES, Copenhagen

> Jaworski A, Ragnarsson SA (2006) Feeding habits of demersal fish in Icelandic waters: a multivariate approach. ICES J Mar Sci 63:1682-1694

- Keenan SF, Benfield MC, Blackburn JK (2007) Importance of the artificial light field around offshore petroleum platforms for the associated fish community. Mar Ecol Prog Ser 331:219-231

> Lindley JA (1982) Population dynamics and production of euphausiids. Mar Biol 66:37-46

Løkkeborg S, Humborstad O, Jørgensen T, Soldal AV (2002) Spatio-temporal variations in gillnet catch rates in the vicinity of North Sea oil platforms. ICES J Mar Sci 59: S294-S299 
Love MS, York A (2005) A comparison of the fish assemblages associated with an oil/gas pipeline and adjacent seafloor in the Santa Barbara Channel, southern California Bight. Bull Mar Sci 77:101-117

Mattson S (1990) Food and feeding habits of fish species over a soft sublittoral bottom in the northeast Atlantic. 1. Cod (Gadus morhua L.) (Gadidae). Sarsia 75:247-260

McConnell A, Routledge R, Connors BM (2010) Effect of artificial light on marine invertebrate and fish abundance in an area of salmon farming. Mar Ecol Prog Ser 419:147-156

Nedreaas K (1987) Food and feeding of young saithe Pollachius virens (L.) on the coast of western Norway. Fiskeridir Skr Ser Havunders 16:263-301

OSPAR (2012) 2012 update of the inventory of oil and gas offshore installations in the OSPAR maritime area. OSPAR Commission, London

Page HM, Dugan JE, Schroeder DM, Nishimoto MM, Love MS, Hoesterey JC (2007) Trophic links and condition of a temperate reef fish: comparisons among offshore oil platform and natural reef habitats. Mar Ecol Prog Ser 344: 245-256

Pradella N, Fowler AM, Booth DJ, Macreadie PI (2014) Fish assemblages associated with oil industry structures on the continental shelf of north-western Australia. J Fish Biol 84:247-255

R Core Team (2013) R: a language and environment for statistical computing. R Foundation for Statistical Computing, Vienna. http: //R-project.org/

Reubens J, Degraer S, Vincx M (2011) Aggregation and feeding behaviour of pouting (Trisopterus luscus) at wind turbines in the Belgian part of the North Sea. Fish Res 108:223-227

Royal Academy of Engineering (2013) Decommissioning in the North Sea. Royal Academy of Engineering, London. www.raeng.org.uk/publications/reports/decommissioning-in-the-north-sea

Russell DJF, Brasseur SMJM, Thompson D, Hastie GD and

Editorial responsibility: Edward Durbin,

Narragansett, Rhode Island, USA others (2014) Marine mammals trace anthropogenic structures at sea. Curr Biol 24:R638-R639

Schückel S, Ehrich S, Kröncke I, Reiss H (2010) Linking prey composition of haddock Melanogrammus aeglefinus to benthic prey availability in three different areas of the northern North Sea. J Fish Biol 77:98-118

> Soldal AV, Svellingen I, Jørgensen T, Løkkeborg S (2002) Rigs-to-reefs in the North Sea: hydroacoustic quantification of fish in the vicinity of a 'semi-cold' platform. ICES J Mar Sci 59:S281-S287

Stanley DR, Wilson CA (1997) Seasonal and spatial variation in the abundance and size distribution of fishes associated with a petroleum platform in the northern Gulf of Mexico. Can J Fish Aquat Sci 54:1166-1176

Stelzenmüller V, Ellis JR, Rogers SI (2010) Towards a spatially explicit risk assessment for marine management: assessing the vulnerability of fish to aggregate extraction. Biol Conserv 143:230-238

Todd VLG, Pearse WD, Tregenza NC, Lepper PA, Todd IB (2009) Diel echolocation activity of harbour porpoises (Phocoena phocoena) around North Sea offshore gas installations. ICES J Mar Sci 66:734-745

- Uglem I, Bjørn PA, Dale T, Kerwath S and others (2008) Movements and spatiotemporal distribution of escaped farmed and local wild Atlantic cod (Gadus morhua L.). Aquacult Res 39:158-170

> Uglem I, Dempster T, Bjorn PA, Sanchez-Jerez P, Økland F (2009) High connectivity of salmon farms revealed by aggregation, residence and repeated movements of wild fish among farms. Mar Ecol Prog Ser 384:251-260

Whomersley P, Picken GB (2003) Long-term dynamics of fouling communities found on offshore installations in the North Sea. J Mar Biol Assoc UK 83:897-901

Wieland K, Pedersen EMF, Olesen HJ, Beyer JE (2009) Effect of bottom type on catch rates of North Sea cod (Gadus morhua) in surveys with commercial fishing vessels. Fish Res 96:244-251

Submitted: March 9, 2015; Accepted: October 27, 2015

Proofs received from author(s): December 14, 2015 